\title{
The dynamics of laterally variable subductions: laboratory models applied to the Hellenides
}

\author{
B. Guillaume ${ }^{1,2,3,4}$, L. Husson ${ }^{1,2,3}$, F. Funiciello ${ }^{4}$, and C. Faccenna ${ }^{4}$ \\ ${ }^{1}$ Géosciences Rennes, Université de Rennes 1, Rennes, France \\ ${ }^{2}$ Géosciences Rennes, CNRS UMR 6118, Rennes, France \\ ${ }^{3}$ Laboratoire de Planétologie et Géodynamique de Nantes, UMR-CNRS 6112, \\ Université de Nantes, Nantes, France \\ ${ }^{4}$ Laboratory of Experimental Tectonics, Dip. di Scienze, Università Roma Tre, Rome, Italy \\ Correspondence to: B. Guillaume (benjamin.guillaume@univ-rennes1.fr)
}

Received: 14 March 2013 - Published in Solid Earth Discuss.: 9 April 2013

Revised: 29 May 2013 - Accepted: 2 June 2013 - Published: 10 July 2013

\begin{abstract}
We designed three-dimensional dynamically selfconsistent laboratory models of subduction to analyse the relationships between overriding plate deformation and subduction dynamics in the upper mantle. We investigated the effects of the subduction of a lithosphere of laterally variable buoyancy on the temporal evolution of trench kinematics and shape, horizontal flow at the top of the asthenosphere, dynamic topography and deformation of the overriding plate. Two subducting units, which correspond to a negatively buoyant oceanic plate and positively buoyant continental one, are juxtaposed via a trench-perpendicular interface (analogue to a tear fault) that is either fully-coupled or shear-stress free. Differential rates of trench retreat, in excess of $6 \mathrm{~cm} \mathrm{yr}^{-1}$ between the two units, trigger a more vigorous mantle flow above the oceanic slab unit than above the continental slab unit. The resulting asymmetrical sublithospheric flow shears the overriding plate in front of the tear fault, and deformation gradually switches from extension to transtension through time. The consistency between our models results and geological observations suggests that the Late Cenozoic deformation of the Aegean domain, including the formation of the North Aegean Trough and Central Hellenic Shear zone, results from the spatial variations in the buoyancy of the subducting lithosphere. In particular, the lateral changes of the subduction regime caused by the Early Pliocene subduction of the old oceanic Ionian plate redesigned mantle flow and excited an increasingly vigorous dextral shear underneath the overriding plate. The models suggest that it is the inception of the Kefalonia Fault that
\end{abstract}

caused the transition between an extension dominated tectonic regime to transtension, in the North Aegean, Mainland Greece and Peloponnese. The subduction of the tear fault may also have helped the propagation of the North Anatolian Fault into the Aegean domain.

\section{Introduction}

At convergent margins, the negative buoyancy of the subducting lithosphere plays a first-order role in driving subduction (Forsyth and Uyeda, 1975; Chapple and Tullis, 1977). Variations in slab buoyancy occur both in time and space, for example during the subduction of oceanic plateaux that tend to decrease the average density of the subducting lithosphere (e.g. Cloos, 1993). Not surprisingly, analogue (Bellahsen et al., 2005; Martinod et al., 2005; Espurt et al., 2008), semi-analytical (Royden and Husson, 2009), and numerical (van Hunen et al., 2002; De Franco et al., 2008; Magni et al., 2012) models show that temporal variations of slab buoyancy exert a primary control on slab dip and migration of the subduction hinge relative to the upper plate. The downdip descent of positively buoyant material into the subduction zone initiates a transient mode during which the slab steepens and the subduction rate decreases. Similarly, mantle flows at lower rates about the slab, and the magnitude of dynamic deflections adjusts within the same characteristic time frame. Less clear is the role of the lateral variations in slab buoyancy on trench migration rates, arc curvature, mantle 


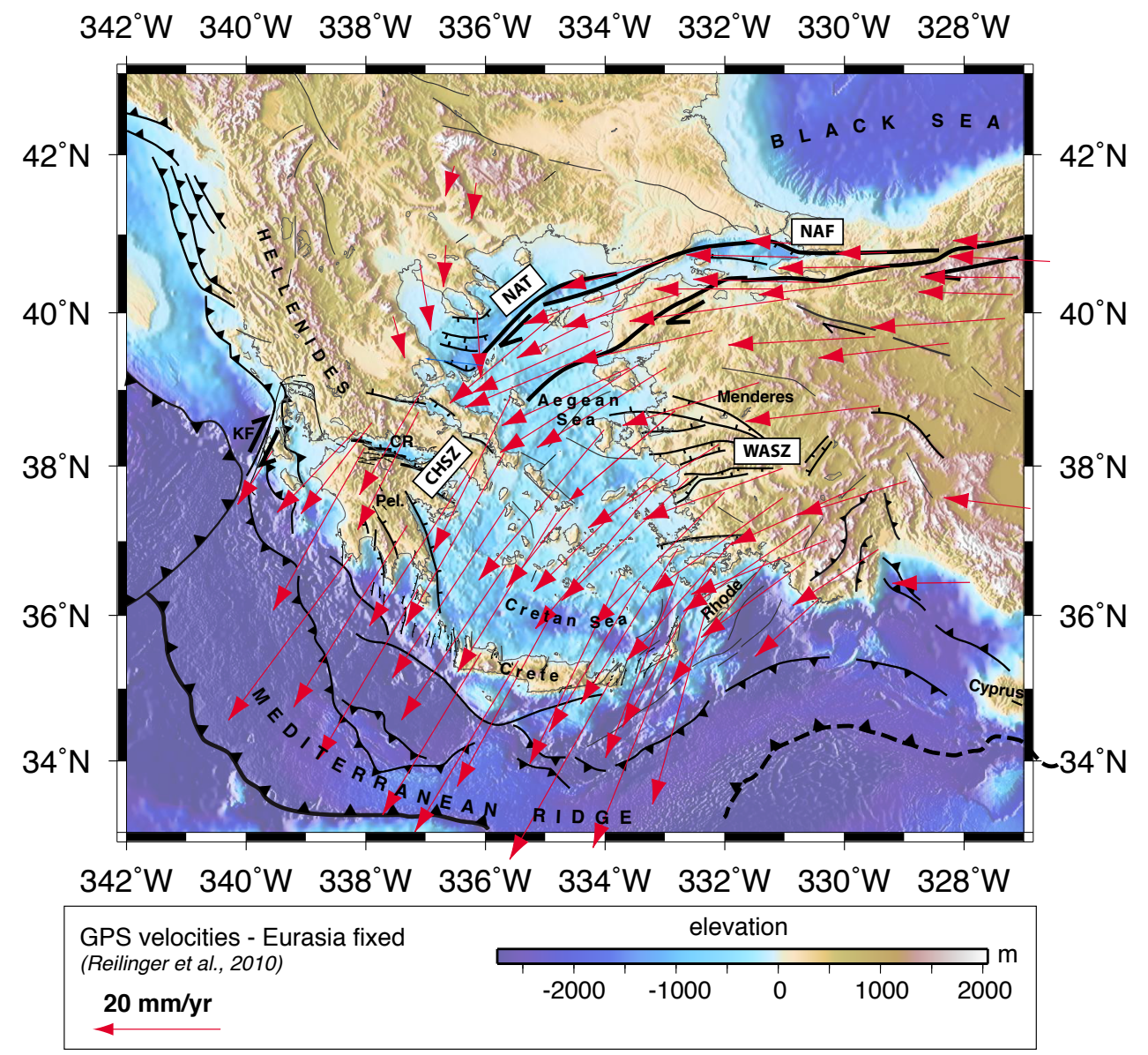

Fig. 1. Tectonic map of the Aegean and Anatolian regions showing the main active structures (after Jolivet et al., 2013) and GPS velocity field (Eurasia fixed, after Reilinger et al., 2010). Topographic data come from the ETOPO1 global relief model (Amante and Eakins, 2009). CHSZ: Central Hellenic Shear Zone; CR: Corinth Rift; KF: Kefalonia Fault; NAF: North Anatolian Fault; NAT: North Aegean Trough; Pel: Peloponnese; WASZ: Western Anatolian Shear Zone.

flow circulation, overriding plate deformation and topography along the subduction zone. Yet, they are common features on Earth, where seamounts, aseismic ridges, continental fragments, stretched continental margins often correspond to lateral variations in the buoyancy of slabs. Their descent into the mantle is expected to affect slab geometry and mantle flow and subsequently, dynamic topography, upper plate strain and trench deformation (Duretz and Gerya, 2013).

Clearcut examples of such settings are the subduction of continental units adjacent to oceanic plates. The Australian continent in the Banda trench subducts underneath the Banda Sea; it is dragged along with the Indian oceanic plate that subducts in its western counterpart Sunda trench (e.g. Carter et al., 1976; Hamilton, 1979; Bowin et al., 1980). Similarly, the Adriatic plate subducts underneath the Apennines; to the south, in the Ionian Sea, the subducting plate is oceanic, possibly the oldest worldwide (Speranza et al., 2012). To the north, the bathymetry is much shallower, which is diagnostic of a continental fragment, less dense than the underlying mantle. Their respective buoyancies are thus extremely contrasted, and the subduction zone reacts accordingly (Royden and Husson, 2009). The lateral continuity of the subducting lithosphere is not entirely resolved, and may vary from one subduction zone to another: tear faults may occasionally adjust the geometry of the slab to the differential motion between the low and high buoyancy units (e.g. Govers and Wortel, 2005; Rosenbaum et al., 2008; Guillaume et al., 2010; Baes et al., 2011). Alternatively, the slab may not be disrupted by tear faults and instead distort, at least during the earlier stages of continental subduction, in order to accommodate the lateral variations in subducting rates (e.g. Spakman and Hall, 2010).

Similar setting prevails across the Adriatic Sea from the Apennines, along the Hellenides (Fig. 1). South of the Kefalonia Fault, the oceanic Ionian plate subducts, whereas to the north, the continental, more positively buoyant unit enters the subduction zone. In spite of a long lasting interest (see Jolivet et al., 2013, for a review), the dynamics of 


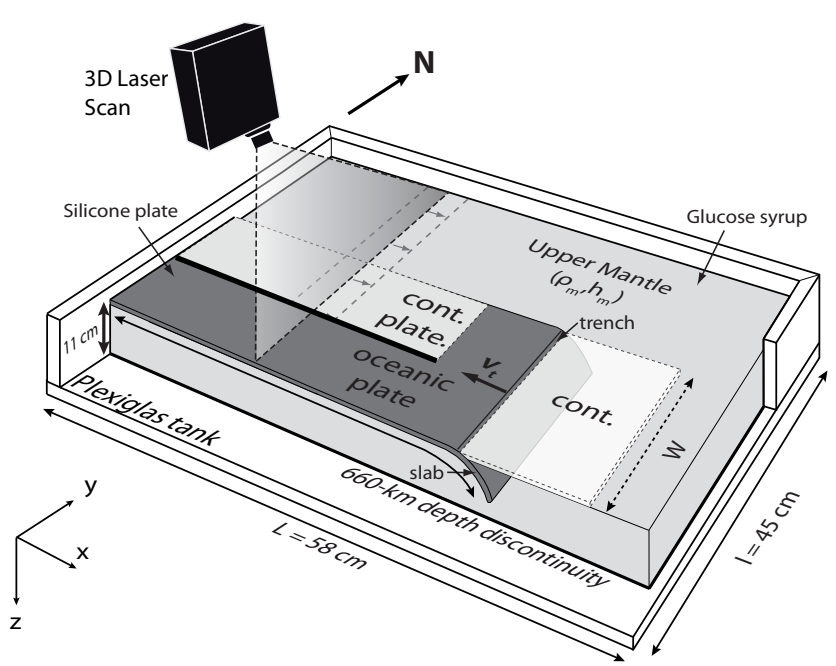

Fig. 2. Experimental setup. The subducting lithosphere is modelled by a silicone plate made of two different materials, a positively buoyant one (defined as continental lithosphere) and a negatively buoyant one (defined as oceanic lithosphere). The upper mantle is simulated by means of glucose syrup, the bottom of the box corresponding to an impermeable lower mantle-upper mantle discontinuity. The plate is fixed, i.e. its trailing edge is attached to the box. The surface topography is monitored by a 3-D laser scan and pictures are taken from the top and the side of the model every $30 \mathrm{~s}$. See Table 1 for experimental parameters.

the Hellenic subduction and Aegean domain bear persisting questions: what are the mechanisms that trigger the late ( $\leq 5 \mathrm{Ma}$, Armijo et al., 1999) propagation of the North Anatolian Fault into the Aegean domain? What are the causes of the rapidly changing structural pattern during Neogene, in the Aegean in general and in particular in the Peloponnese and Mainland Greece, around the Corinth rift (Papanikolaou and Royden, 2007)? How do these events relate to the disruption of the Hellenic arc by the Kefalonia Fault?

We thus perform a set of dynamically self-consistent 3-D laboratory models, in which no external kinematic boundary conditions, such as plate or trench velocity, are applied, to test the influence of the arrival at trench of a laterally heterogeneous lithosphere, positively buoyant on half the width of the subduction zone (referred to as continental lithosphere in the following) and negatively buoyant on the other half (oceanic lithosphere in the following), on the subduction dynamics. We further test the role of the shear stresses along the interface between the continental and oceanic plates, that we herein generically name tear fault, on the modulation of the dynamics. We finally analyse the well-documented tectonic evolution of the Aegean domain at the light of our models.

\section{Models}

Our simplified subduction system is designed to reproduce the force balance in natural subduction zones, which means that the slab drives the mantle flow and its motion is resisted by viscous dissipation in the mantle, in the slab, in the overriding plate and at the plates interface (De Franco et al., 2008; Zhong and Gurnis, 1994). We performed a total of 11 models, following the experimental procedure proposed by $\mathrm{Fu}-$ niciello et al. (2003) and Bellahsen et al. (2005) (Table 1). The set of models aims at exploring how the lateral variation in slab buoyancy affects the kinematics of the trench, mantle flow, dynamic topography and upper plate deformation. In the following, only 4 of the 11 models will be described in details while the others serve as a background for our analysis. The modelled subducting lithosphere has been divided into a positively buoyant portion and a negatively buoyant portion (Fig. 2). Such an approach has already been used to study how the subduction of positively buoyant ridges and oceanic plateaux impact the subduction dynamics (Martinod et al., 2005; Espurt et al., 2008; Martinod et al., 2013). To compare the experimental results to the kinematics of the Hellenic subduction, we restrict the length of the subduction zone within the range $1200-2400 \mathrm{~km}$ and we fix the subducting plate at its trailing edge, in analogy with the Hellenic subduction zone that is embedded into the massive, slowly moving African plate.

\subsection{Setup}

We use silicone putty (Rhodrosil Gomme, PDMS + iron fillers) and glucose syrup to model the lithosphere and the upper mantle, respectively. Silicone putty is a viscoelastic material. However, it can be considered as a quasi-newtonian fluid since the elastic component is negligible for the applied low experimental strain rates (Weijermars and Schmeling, 1986). Glucose syrup is a transparent newtonian low-viscosity fluid. These materials have been selected to achieve the standard scaling procedure for stresses scaled down for length, density and viscosity in a natural gravity field as described by Weijermars and Schmeling (1986) and Davy and Cobbold (1991).

The scale factor for length is $1.67 \times 10^{-7}(1 \mathrm{~cm}$ in the model corresponds to $60 \mathrm{~km}$ in nature). Densities and viscosities are assumed to be constant over the thickness of the individual layers and are considered to be averages of the actual values. Scaling for time $t$ is given by

$t_{\text {nature }}=\frac{(\Delta \rho h)_{\text {model }} \cdot \eta_{\text {nature }}}{(\Delta \rho h)_{\text {nature }} \cdot \eta_{\text {model }}} \times t_{\text {model }}$

where $\Delta \rho$ is the density contrast between the subducting plate and upper mantle, $h$ is the slab thickness, and $\eta$ the mantle viscosity. The density contrast $\Delta \rho$ between oceanic lithosphere and mantle ranges from 71 to $83 \mathrm{~kg} \mathrm{~m}^{-3}$ (corresponding to a $40 \mathrm{Myr}$-old oceanic lithosphere with a $80 \%$ 
Table 1. Experimental parameters. $L$ : length; $W:$ width; $h$ : thickness; $\Delta \rho: \rho-\rho_{\text {mantle }} ; \eta^{*}: \eta / \eta_{\text {mantle }}$. Considering a natural case with the following parameters $\left(h_{\text {slab }}=72 \mathrm{~km} ; \eta_{\text {mantle }}=1 \times 10^{20} \mathrm{Pas}\right.$ and $\left.\Delta \rho_{\text {slab }}=71 \mathrm{~kg} \mathrm{~m}^{-3}\right), 1 \mathrm{~km}$ in nature corresponds to $0.14 \mathrm{~mm}$ in the lab, a period of $1 \mathrm{Myr}$ in nature corresponds to $57 \mathrm{~s}$ in the lab, and a velocity of $10 \mathrm{~cm} \mathrm{yr}^{-1}$ in nature to a velocity of $17.6 \mathrm{mmmin}^{-1}$ in the lab (models 8-11).

\begin{tabular}{|c|c|c|c|c|c|c|c|c|c|c|c|c|c|c|c|}
\hline \multirow[b]{2}{*}{ Model } & \multicolumn{5}{|c|}{ Oceanic lith. } & \multicolumn{5}{|c|}{ Continental lith. } & \multicolumn{5}{|c|}{ Continent } \\
\hline & $\begin{array}{c}L \\
\mathrm{~cm}\end{array}$ & $\begin{array}{l}W \\
\mathrm{~cm}\end{array}$ & $\begin{array}{c}h \\
\mathrm{~cm}\end{array}$ & $\begin{array}{c}\Delta \rho \\
\mathrm{kg} \mathrm{m}^{-3}\end{array}$ & $\begin{array}{c}\eta^{*} \\
\times 10^{2}\end{array}$ & $\begin{array}{c}L \\
\mathrm{~cm}\end{array}$ & $\begin{array}{l}W \\
\mathrm{~cm}\end{array}$ & $\begin{array}{c}h \\
\mathrm{~cm}\end{array}$ & $\begin{array}{c}\Delta \rho \\
\mathrm{kg} \mathrm{m}^{-3}\end{array}$ & $\begin{array}{c}\eta^{*} \\
\times 10^{2}\end{array}$ & $\begin{array}{c}L \\
\mathrm{~cm}\end{array}$ & $\begin{array}{c}W \\
\mathrm{~cm}\end{array}$ & $\begin{array}{c}h \\
\mathrm{~cm}\end{array}$ & $\begin{array}{c}\Delta \rho \\
\mathrm{kg} \mathrm{m}^{-3}\end{array}$ & $\begin{array}{c}\eta^{*} \\
\times 10^{2}\end{array}$ \\
\hline 1 & 35 & 20 & 1.2 & 83 & 9.1 & 21 & 10 & 1.2 & -35 & 8.5 & 16 & 25 & 1.0 & -35 & 8.5 \\
\hline 2 & 40 & 20 & 1.2 & 83 & 7.75 & 20 & 10.5 & 1.2 & -41 & 17 & 18 & 25 & 0.9 & -35 & 7.25 \\
\hline 3 & 45 & 20 & 1.2 & 83 & 7.75 & 25 & 10 & 1.2 & -41 & 17 & - & - & - & - & - \\
\hline 4 & 45 & 40 & 1.2 & 83 & 7.75 & 25 & 20 & 1.2 & -41 & 17 & - & - & - & - & - \\
\hline 5 & 45 & 40 & 1.2 & 83 & 7.75 & 25 & 20 & 1.2 & -41 & 17 & - & - & - & - & - \\
\hline 6 & 45 & 40 & 1.2 & 83 & 7.75 & 25 & 20 & 1.2 & -41 & 17 & - & - & - & - & - \\
\hline 7 & 45 & 40 & 1.2 & 83 & 7.75 & 25 & 20 & 1.2 & -41 & 17 & 20 & 40 & 0.5 & -35 & 7.25 \\
\hline 8 & 45 & 40 & 1.2 & 71 & 11.5 & 25 & 20 & 1.2 & -43 & 25 & - & - & - & - & - \\
\hline 9 & 45 & 30 & 1.2 & 71 & 11.5 & 25 & 15 & 1.2 & -43 & 25 & - & - & - & - & - \\
\hline 10 & 45 & 20 & 1.2 & 71 & 11.5 & 25 & 10 & 1.2 & -43 & 25 & - & - & - & - & - \\
\hline 11 & 45 & 20 & 1.2 & 71 & 11.5 & 25 & 10 & 1.2 & -43 & 25 & - & - & - & - & - \\
\hline
\end{tabular}

eclogitized crust; see Cloos, 1993) and that of the continental lithosphere between -35 and $-43 \mathrm{~kg} \mathrm{~m}^{-3}$ (corresponding to a continental lithosphere with a crust thickness of $\sim 16 \mathrm{~km}$ and a density of 2.75 , in the range of crustal thickness found for the subducting lithosphere beneath the Northern Hellenides (20km; Pearce et al., 2012)) (Table 1). When present, the overriding lithosphere is positively buoyant with $\Delta \rho=-35 \mathrm{~kg} \mathrm{~m}^{-3}$. The viscosities of the lithospheres and upper mantle are measured with a rheometer (Physica MCR 301, Anton Paar). At room temperature and for strain rates ranging between $10^{-4} \mathrm{~s}^{-1}$ and $10^{-3} \mathrm{~s}^{-1}$, the viscosity of the silicone putty used for the oceanic lithosphere is $3.2 \times 10^{4} \mathrm{Pas}$ and the viscosity of the continental lithosphere is either $2.9 \times 10^{4} \mathrm{Pas}$ for model 1 or $6.8 \times 10^{4} \mathrm{Pas}$ for the other ones. Viscosity of the overriding lithosphere, when present, is $2.9 \times 10^{4} \mathrm{Pas}$ and the viscosity of the mantle ranges between 30 and 40 Pas. The obtained viscosity ratio between the slab and the upper mantle varies between $7.75 \times 10^{2}$ and $25 \times 10^{2}$ (Table 1), which is in the high range of proposed values (e.g. Billen et al., 2003; Faccenna et al., 2007; Funiciello et al., 2008; Wu et al., 2008; Loiselet et al., 2009, 2010). In the following, we directly express the quantities with their corresponding scaled values for a better relevance to real Earth.

The mechanical behaviour of the trench-perpendicular boundary between the oceanic and continental lithospheres exerts a primary control on the evolution of subduction. Because the lithosphere in our experiments is simulated by the means of an unstratified mechanical layer with a Newtonian rheology, its deformation is not localised enough to spontaneously form a vertical tear fault during the subduction. We thus consider two end-members, in which the behaviour of the discontinuity is ascribed a priori, by artificially switching on and off the shear stresses at the boundary between the two plates: (i) no lithospheric tear fault: we assume that differential buoyancy forces and rheological properties do not meet the conditions required to trigger the rupture of the lithosphere. The evolution of the oceanic and continental portions of the subducting lithosphere stay interdependent during the time of the experiment; (ii) preexisting tear fault: we assume that the rupture is instantaneous and localised at the transition between oceanic and continental lithospheres. In practice, this second case is obtained by forming a pre-existing structure precutting the subducting lithosphere at the transition between negatively- and positively-buoyant lithospheres and filling in the created gap with petroleum jelly that prevents the two plates of silicone to stick together again during the experiment. Mechanically, the viscosity of the employed petroleum jelly is so low that it implies shear stresses (but not the normal stresses) are negligible between the two plates.

\subsection{Experimental procedure}

The silicone plates are initially floating above the glucose syrup and their trailing edges are attached to the box in order to preclude any trenchward motion of the subducting plate (fixed edge subduction sensu Kincaid and Olson, 1987), in which absolute motion of the subducting lithosphere is null with respect to the lower mantle (Fig. 2). Assuming negligible horizontal strain of the subducting lithosphere, the rate of trench motion equals the rate of subduction. Spontaneous sinking of the negatively buoyant oceanic lithosphere, that initially floats over the syrup, is avoided by surface tension exerted by the syrup onto the silicone plate. The experimental subduction is always initiated by forcing the leading edge of the silicone plate into the glucose syrup to a depth of $\sim 2 \mathrm{~cm}$ (corresponding to about $120 \mathrm{~km}$ in nature). We ensure that the subduction is at steady state (see Funiciello et al., 2003) 
a

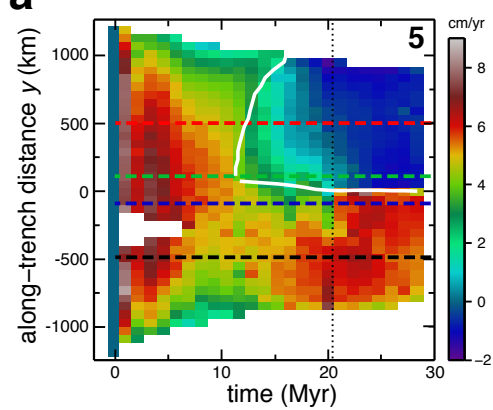

C

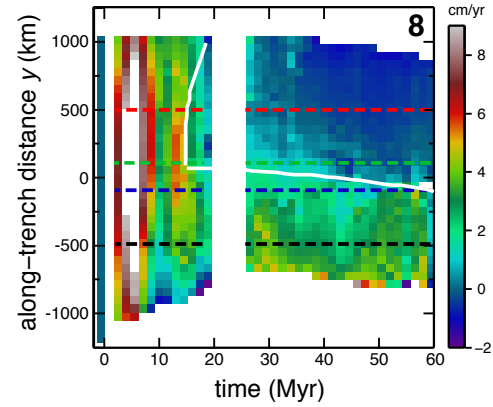

e

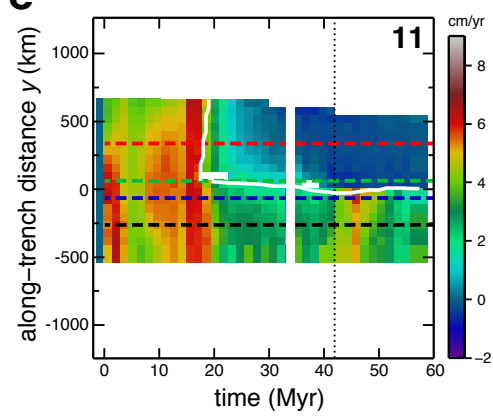

g

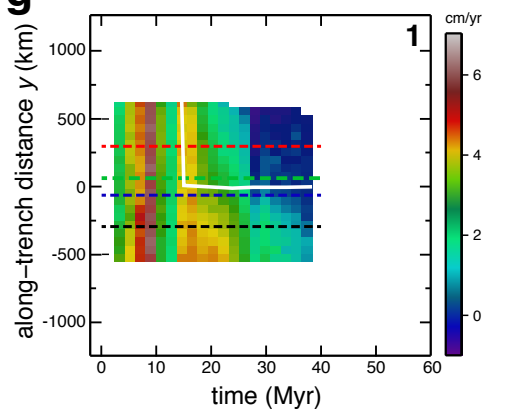

b

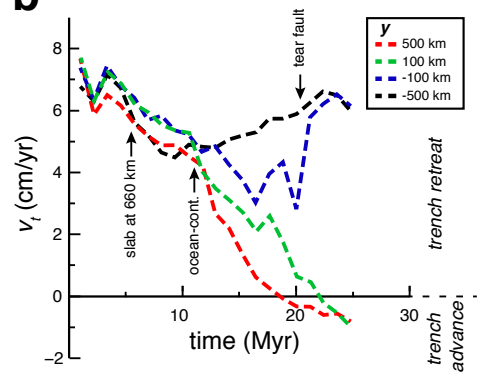

d

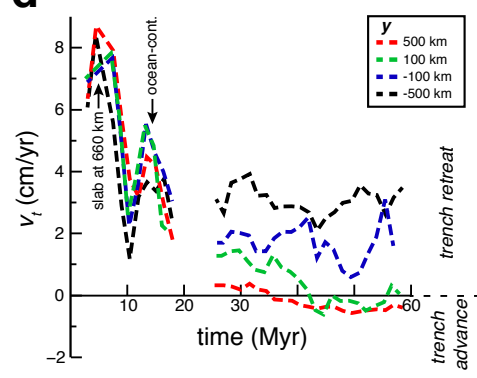

f

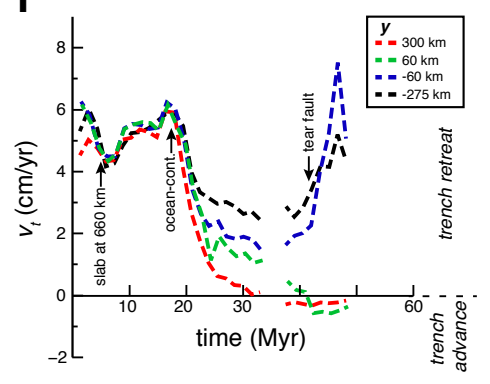

h

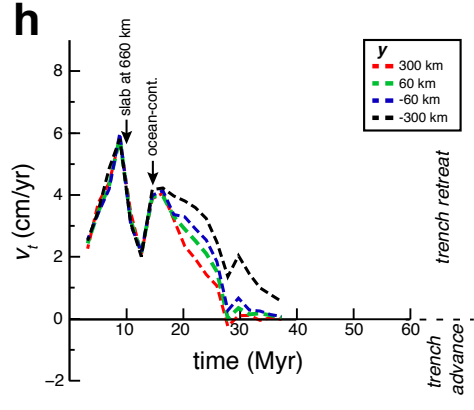

Fig. 3. (a) Trench migration rate as a function of time along y-axis for model 5, i.e. a large subduction zone with a vertical tear fault developing after 20.5 Myr of subduction (black dotted line). Zero on the y-axis corresponds to the location of the discontinuity between oceanic and continental lithospheres. Positive and negative values indicate oceanward and continentward trench motions, respectively. A solid white line underlines the onset of continental lithosphere subduction. (b) Trench migration rate as a function of time for sections located $500 \mathrm{~km}$ (red line) and $100 \mathrm{~km}$ (green line) north of the discontinuity and $100 \mathrm{~km}$ (blue line) and $500 \mathrm{~km}$ (black line) south of it (see location on Fig. $3 \mathrm{a}$ ). Slab reaches the upper-lower mantle discontinuity after 6 Myr. Subduction of the positively-buoyant slab starts after 11 Myr. (c) Same as (a) but for a large subduction zone without a vertical tear fault (model 8). The area in white corresponds to a period of no data acquisition. (d) Same as (b) but for model 8. (e) Same as (a) for a narrow subduction zone with a vertical tear fault developing after $42 \mathrm{Myr}$ (model 11). (f) Same as (b) but for model 11 and sections located $300 \mathrm{~km}$ (red line) and $60 \mathrm{~km}$ (green line) north of the discontinuity and $60 \mathrm{~km}$ (blue line) and $275 \mathrm{~km}$ (black line) south of it (see location on Fig. 3e). (g) Same as (a) for a narrow subduction zone with an overriding plate (model 1). (h) Same as (b) but for model 1. 
before the lateral transition between oceanic and continental lithospheres enters the trench. In order to meet this condition and only identify the effects of the lateral variations in slab buoyancy, the leading part of the subducting plate is made of $1200 \mathrm{~km}$-long oceanic lithosphere. For descriptive convenience, we geographically orient our models, such that West is on the foreland side of the plate (the unsubducted part of the plate).

When present, the overriding plate is decoupled from the subducting plate by a thin layer of glucose syrup (see Heuret et al., 2007; Espurt et al., 2008; Guillaume et al., 2009), which reduces the shear stresses to negligible values (because stresses scale with viscosity) and prevents plates sticking to one another. It is somehow equivalent to introducing a weak zone in numerical models that is used to mimic the effect of a fault subduction zone (e.g. Zhong and Gurnis, 1994; Gérault et al., 2012).

The glucose syrup in some of the models is initially seeded with highly reflecting air micro-bubbles. These bubbles are used as passive tracers to map the upper mantle circulation pattern and to quantify the related velocity field using the image analysis technique denoted as Particle Image Velocimetry using the MatPIV 1.6.1 toolbox (Sveen, 2004). We assume that tracers only slightly influence the density and viscosity of the mantle fluid, as in Funiciello et al. (2006). For models $8-11$, when steady state is reached, the surface is spray-painted (in order to overcome optical issues due to the translucency of the glucose syrup) and scanned with a 3-D scanner (EScan 3-D Imaging System), which acquires the topography with a maximum horizontal resolution of $0.13 \mathrm{~mm}$ ( $\sim 800 \mathrm{~m}$ in nature). The precision of topographic data is $0.05 \mathrm{~mm}$ (300 $\mathrm{m}$ in nature).

\section{Modeling results}

Lateral variations of slab buoyancy are accounted for by locally changing the density contrast between the slab and surrounding mantle. At this transition, the two units are either decoupled from one another by a preexisting lithospheric tear fault or not.

\subsection{Trench kinematics}

\subsubsection{Large subduction zone with tear faulting (model 5)}

The trench in model 5 is $2400 \mathrm{~km}$ large. W-E trench migration rate $\left(v_{\mathrm{t}}\right)$ is computed for $90 \mathrm{~s}(\sim 1.2 \mathrm{Myr})$ time steps and $1 \mathrm{~cm}(60 \mathrm{~km})$ steps along the trench (Fig. 3a, b). Trench kinematics follow a 4 stage evolution, as also recorded in models 4 and 6: i. For the first $6 \mathrm{Myr}$, the oceanic plate is sinking into the upper mantle, slab pull force progressively increases and trench retreat velocity reaches values as high as 6$8 \mathrm{~cm} \mathrm{yr}^{-1}$ (Fig. 3a, b).

ii. Once the slab reaches the bottom of the box, oceanward trench motion slows down and stabilises at $\sim 4.5$ $-5 \mathrm{~cm} \mathrm{yr}^{-1} \cdot v_{\mathrm{t}}$ is slightly higher in the centre of the subduction zone with values of $\sim 5-5.5 \mathrm{~cm} \mathrm{yr}^{-1}$ (Fig. 3a, b).

iii. The third stage starts with the onset of continental lithosphere subduction in the northern half of the subduction zone after $11 \mathrm{Myr}$ and stops when the offset along the vertical tear fault in the centre of the subduction zone develops after 20.5 Myr. In the northern part, the average negative slab buoyancy progressively decreases, and the subduction and trench velocities drop. In the centre of the northern unit $(y=500 \mathrm{~km})$, trench motion switches from retreat to - moderate - advance after a period of $\sim 8 \mathrm{Myr}$ (Fig. 3a, b) when $\sim 125 \mathrm{~km}$ of continental lithosphere has subducted. We found similar results for model 8, which incorporates an overriding plate. Closer to the lateral transition between continental and oceanic units $(y=100 \mathrm{~km})$, the decrease in trench migration rate is slower; for the $9.5 \mathrm{Myr}$ duration of this third stage trench velocity drops from 5 to $0.5 \mathrm{~cm} \mathrm{yr}^{-1}$ (Fig. 3a, b). On the oceanic side $(y=-100 \mathrm{~km})$, the decrease of $v_{\mathrm{t}}$ is more limited, with values just below $3 \mathrm{~cm} \mathrm{yr}^{-1}$ after $20.5 \mathrm{Myr}$. Farther from the central discontinuity $(y=-500 \mathrm{~km})$, the arrival at trench to the north of the continental lithosphere does not decrease the trench retreat velocity, as observed elsewhere. Instead, $v_{\mathrm{t}}$ slightly increases from 5 to $6 \mathrm{~cm} \mathrm{yr}^{-1}$ between $11 \mathrm{Myr}$ and 20.5 Myr (Fig. 3a, b), meaning that the lateral influence of a decrease in slab buoyancy vanishes at remote locations $(>500 \mathrm{~km})$. We also observe a $1 \mathrm{cmyr}^{-1}$ increase in trench retreat on a $\sim 10 \mathrm{Myr}$ interval in the centre of the oceanic unit for model 8 . However, the additional overriding plate dragging results in lower values of trench retreat, from $\sim 2.5$ to 3.5 $\mathrm{cm} \mathrm{yr}^{-1}$.

iv. After 20.5 Myr, the differential trench retreat motion between the oceanic and continental units offsets the two plates along a vertical tear fault (Figs. 3a, b and 4a). On its northern edge $(y=100 \mathrm{~km}), v_{\mathrm{t}}$ keeps decreasing and eventually switches from oceanward to continentward motion with values up to $1 \mathrm{cmyr}^{-1}$ (Fig. 3a, b). Instead, on its southern edge $(y=-100 \mathrm{~km}), v_{\mathrm{t}}$ instantaneously increases from 3 to $6 \mathrm{~cm} \mathrm{yr}^{-1}$. Farther from the tear fault, changes in trench kinematics are less important. In the centre of the southern unit $(y=-500 \mathrm{~km}), v_{\mathrm{t}}$ slightly increases to $\sim 6.5 \mathrm{~cm} \mathrm{yr}^{-1}, \sim 30 \%$ higher than trench retreat velocity during stage 2 when the width of the slab was about twice as large. Finally, the limited 

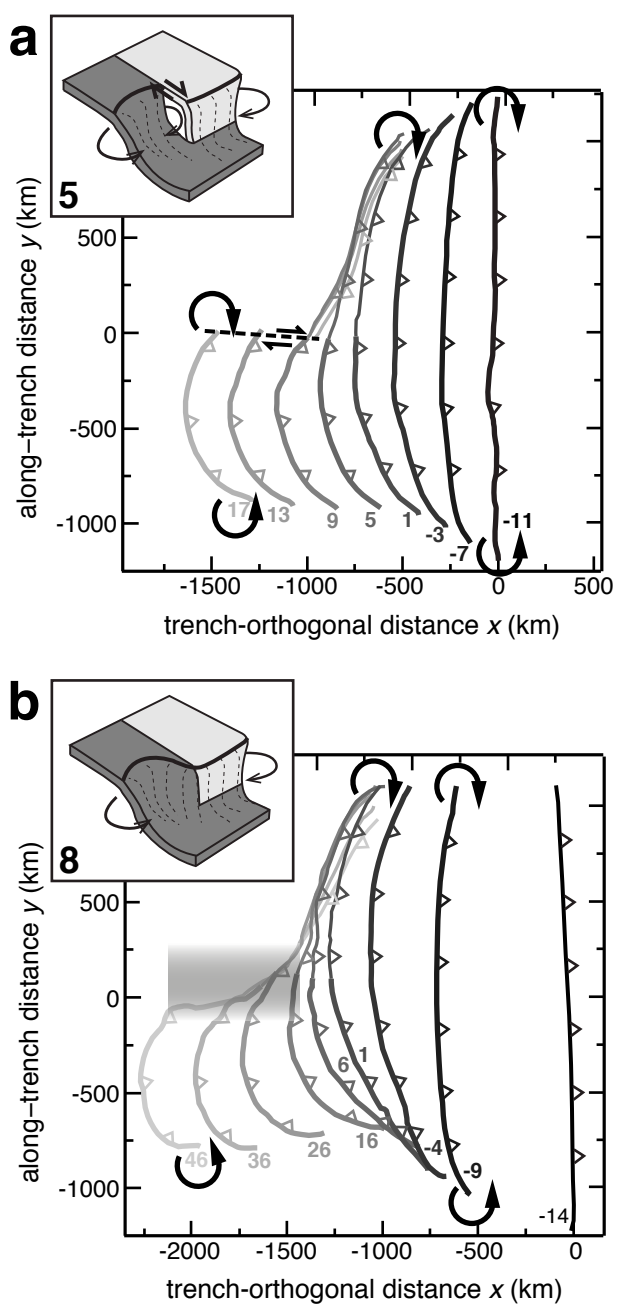

Fig. 4. Evolution of horizontal trench shape for models (a) 5 and (b) 8. Thick and thin lines indicates locations of oceanic and continental subductions, respectively. Numbers at the bottom indicate the time after subduction of continental lithosphere in Myr. Dashed line in (a) indicates the location of the tear fault and grey box in (b) the area where the slab deforms to accommodate differential roll-back velocities. Black arrows show schematic mantle flow pattern associated with subduction. Insets show 3-D sketches of the subducting plate shape at the end of each experiment.

decrease in $v_{\mathrm{t}}$ to the south of the tear fault after $\sim 23$ $24 \mathrm{Myr}$ are edge effects, as the slab reaches the end wall of the tank.

The roll-back of slabs causes the development of toroidal cells at slab edges (Dvorkin, 1993; Funiciello et al., 2004; Schellart, 2004; Funiciello et al., 2006; Piromallo et al., 2006). In the model, the persistent rollback of the oceanic lithosphere to the south excites such a mantle flow that opposes the roll-back of the northern continental lithosphere, which explains the decreasing $v_{\mathrm{t}}$, and even slight advance, to the north.

\subsubsection{Large subduction zone without tear faulting (model 8)}

In this model, the subduction of positively buoyant lithosphere after $15 \mathrm{Myr}$ also strongly modifies the trench kinematics (Fig. 3c, d). But unlike model 5, along-trench variations of trench velocity are less pronounced. In details, $10 \mathrm{Myr}$ after the entry of positively buoyant lithosphere, the difference of trench velocity between regions located $500 \mathrm{~km}$ north and south of the discontinuity is $\sim 3 \mathrm{~cm} \mathrm{yr}^{-1}$, half the value observed for model $5\left(6 \mathrm{~cm} \mathrm{yr}^{-1}\right)$ (Fig. $3 b$, d). It also holds for regions closer to the discontinuity. The difference in trench velocity $15 \mathrm{Myr}$ after the onset of continental subduction between regions located $100 \mathrm{~km}$ away from the discontinuity is restricted to $\sim 1 \mathrm{~cm} \mathrm{yr}^{-1}$ for model 8 as opposed to $\sim 6 \mathrm{~cm} \mathrm{yr}^{-1}$ for model 5 (Fig. 3c, d). Because in the absence of a tear fault, shear stresses are high between the two plates, they remain coupled throughout and the kinematic evolution of the north and south trenches is never independent from one another. Thus, the absence of slab segmentation at the junction between regions with variable buoyancy results in a global slow down of trench motion along the entire subduction zone.

\subsubsection{Narrow subduction zone with tear faulting (model 11)}

Width of the plate has no significant influence on the evolution of subduction in the models. Indeed, both model 9 and 11 , which share the same set-up as model 5 excepted the subduction zone width that is 1800 - and $1200-\mathrm{km}$ large, respectively, instead of $2400 \mathrm{~km}$, follow a comparable 4 stage evolution (Fig. 3e, f). In the following, we only discuss results from the end-member (model 11).

During stage 2, the trench migrates slightly faster in model 11 than in model 5 (5.5-6 vs. $5 \mathrm{~cm} \mathrm{yr}^{-1}$ ), in agreement with previous models that show that narrower slabs retreat faster (Guillaume et al., 2010). At the beginning of stage 3 after $18 \mathrm{Myr}$, trench retreat velocity decreases all along the subduction zone. In the centre of the oceanic unit of the subducting lithosphere, where the migration rate slightly increases in model 5 , model 11 instead shows a $50 \%$ decrease of $v_{\mathrm{t}}$.

There is also a delay in the time of tear faulting with respect to the large subduction zone model. It occurs $\sim 25 \mathrm{Myr}$ after the positively buoyant unit reaches the trench in model 11 instead of $10 \mathrm{Myr}$ in model 5. This can be explained by the lateral lower variability in trench migration rate that increases the delay necessary for the tear fault to open. In both cases however, the segmentation of the slab at depth occurs when the difference in amount of trench retreat between both sides of the discontinuity reaches values of $200-250 \mathrm{~km}$. 

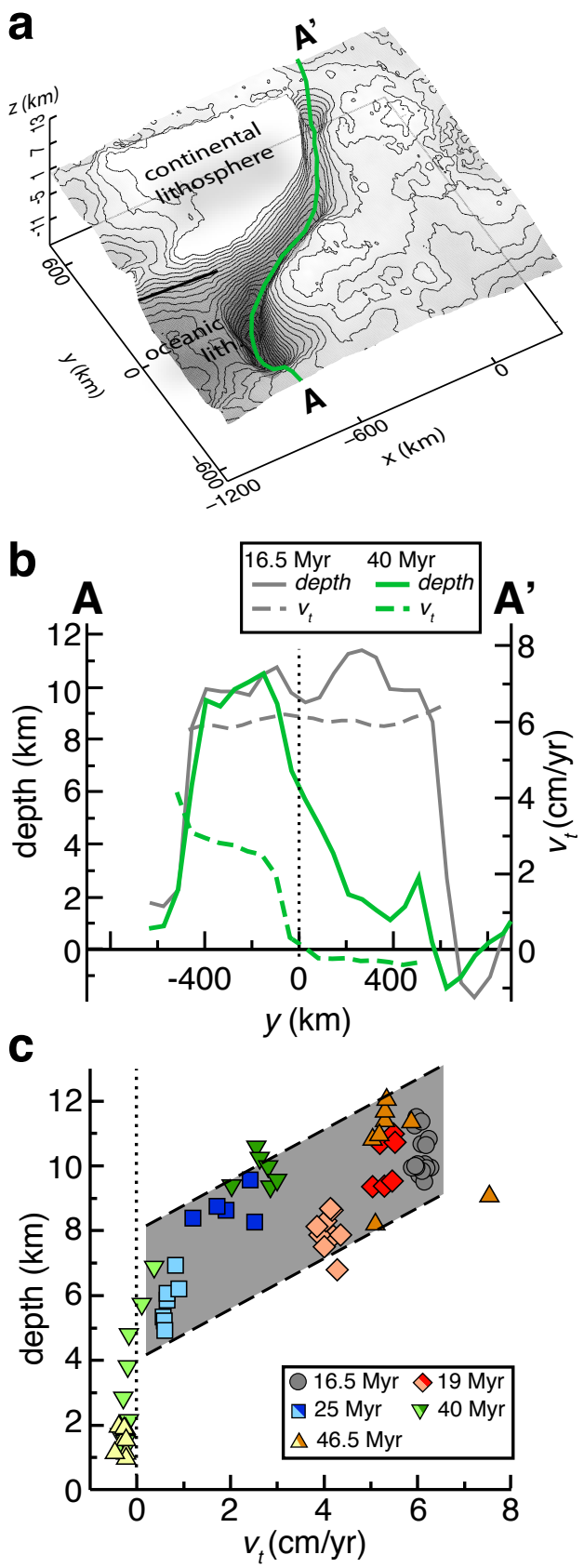

Fig. 5. (a) Digital Elevation Model for the surface of model 11 after $40 \mathrm{Myr}$ of subduction. Zero is the average elevation of the glucose syrup away from the subduction zone. (b) Maximum trench depth (solid line) and corresponding trench migration rate along y-direction (dashed line) after 16.5 Myr (in gray) and $40 \mathrm{Myr}$ (in green) of subduction. (c) Trench maximum depth as function of $v_{\mathrm{t}}$ at different times during subduction. Light and dark symbols correspond to points located in front of continental and oceanic units, respectively. To minimise boundary effects, only points located within a distance of $400 \mathrm{~km}$ from the centre of the subduction zone are included. Dashed lines and grey box indicate the regression envelope for $v_{\mathrm{t}}>0$.

\subsection{Trench shape and depth}

Figure 4 shows the evolution of trench shape through time for the large subduction zone models with (5) or without (8) tearing. At first order, both models share a common geometry that is controlled by the along-trench variability of trench motion. During stages 1 and 2, the trench retreats faster at the centre of the subduction zone than along the edges, which promotes trench curvature. After the arrival of continental lithosphere to the north, the trench remains almost stationary in the northern part whereas in the southern part roll-back of the subducting plate continues. This subsequently causes the formation of a concave trench to the south and an almostlinear trench to the north. The transition is sharp in model 5. The lithospheric fault offsets the trench position at an average velocity of $\sim 7 \mathrm{~cm} \mathrm{yr}^{-1}$, giving a cumulative offset of $500 \mathrm{~km}$ after 7 Myr. Model 8 instead shows continuous transitions from fast trench retreat south of the discontinuity to a stationary - or slowly advancing - trench to the north $\sim 16 \mathrm{Myr}$ after continental subduction. The difference is here accommodated by slab deformation on a roughly $400 \mathrm{~km}$ wide band (Fig. 4b).

Trench depth is also sensitive to along-trench variations in slab buoyancy. We scanned the surface elevation of the model (Fig. 5a) in order to compare the along-trench variations of minimum trench elevation with the corresponding trench migration rate for model 11 (Fig. 5b). Before the subduction of the buoyant lithosphere (16.5 Myr), both trench elevation and trench migration rate are uniform along the entire subduction zone with a $\sim 10 \mathrm{~km}$ deep trench (below reference level, here the mean mantle surface elevation far from the subduction zone) associated to a trench velocity of $6 \mathrm{~cm} \mathrm{yr}^{-1}$. Instead, after $40 \mathrm{Myr}$, when up to $250 \mathrm{~km}$ of buoyant material has entered the trench, trench elevation varies laterally, with a maximum depth in front of the continental unit restricted to $\sim 2 \mathrm{~km}$. Figure $5 \mathrm{c}$ displays the relationship between trench velocity and trench elevation for points sampled every $60 \mathrm{~km}$ along the trench at different times of the same model. Faster trench migration rates match deeper trenches. In these models, the trench depth results from the competition between the buoyancy stresses in the glucose syrup, that tend to restore uniformity, and the shear stresses exerted by the slab that impose the downward flow of the glucose syrup (see Husson et al., 2012). Response of trench topography to variations of trench kinematics is instantaneous and for instance, faster trench retreat of the oceanic part of the subduction zone occurring after slab segmentation at $42 \mathrm{Myr}$ results in a deepening of the trench, from 9 to $11 \mathrm{~km}$ at $40 \mathrm{Myr}$ to 11 to $12 \mathrm{~km}$ at $46.5 \mathrm{Myr}$ (Fig. 5c). Although the shear stresses between the slab and mantle linearly depend on trench velocity, the relationship shown on Fig. 5c breaks down for low trench retreat rates or advancing trenches because of the effect of surface tension whose magnitude is independent on the kinematics. 
a velocity field
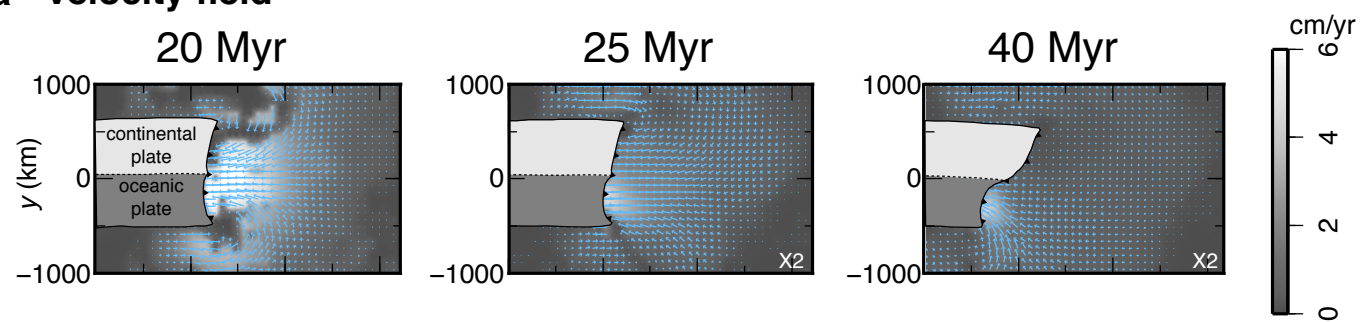

b W-E component
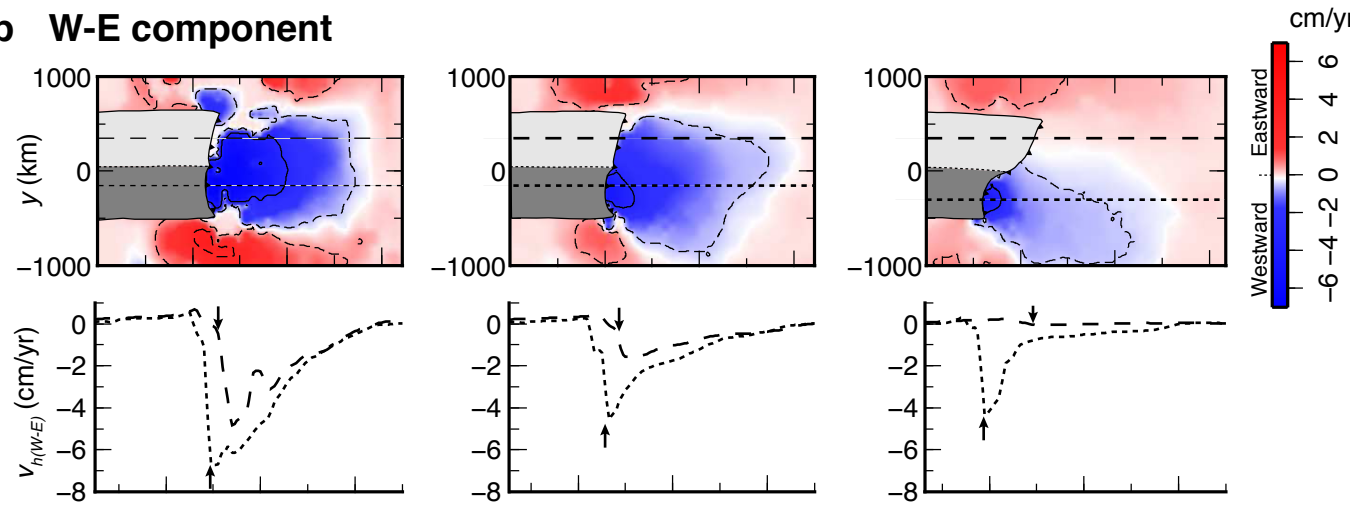

c N-S component
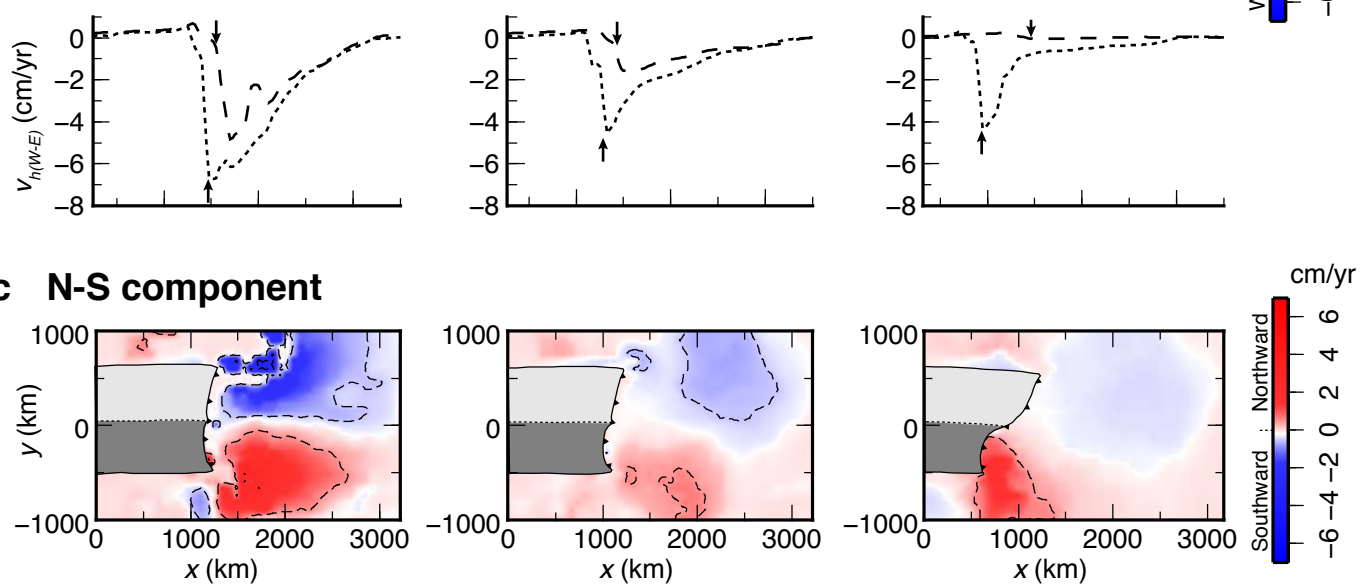

Fig. 6. (a) Velocity vectors and magnitude of the horizontal velocity field for model 11 after $20 \mathrm{Myr}$ (left panel), $25 \mathrm{Myr}$ (central panel) and $40 \mathrm{Myr}$ (right panel) of subduction. Note the changing size of the arrows. (b) Magnitude and along-x profiles of the W-E component of the velocity field. On the maps, black dashed lines underline regions with horizontal mantle flow velocity $\left(v_{\mathrm{h}}\right)$ higher than $0.5 \mathrm{~cm} \mathrm{yr}^{-1}$ and black solid lines with $v_{\mathrm{h}}>4 \mathrm{~cm} \mathrm{yr}^{-1}$. Positions of continental and oceanic units of the subducting plate are indicated in light grey and dark grey, respectively, and the position of the trench by a black line with triangles. W-directed mantle flow is represented as negative values. Profiles pass through the centre of the continental (dashed line) and oceanic (dotted line) units. Black arrows indicate the position of the trench. (c) Same as (b) but for the N-S component of the velocity field. Southward mantle flow is represented as negative values.

\subsection{Mantle flow}

Horizontal velocities $\left(v_{\mathrm{h}}\right)$ are computed at the surface of the glucose syrup and silicone plate in the model 11 (that has no upper plate) using Particle Image Velocimetry (PIV) on top-view images with a pixel resolution of $0.25 \mathrm{~mm}$ and time intervals of $30 \mathrm{~s}$. PIV relies on basic pattern matching, which reconstructs the Eulerian velocity field on a regular grid (Adrian, 1991; Nogueira et al., 2001, among others). We use a multipass cross-correlation analysis with a $50 \%$ overlap of the interrogation regions.

Figure 6 displays the horizontal velocity vectors and the magnitude of both $\mathrm{W}-\mathrm{E}$ and $\mathrm{N}-\mathrm{S}$ components of the horizontal velocity field $20 \mathrm{Myr}, 25 \mathrm{Myr}$ and $40 \mathrm{Myr}$ after subduction initiation for model 11 . During the early stage of uniform subduction (20 Myr), the roll-back motion of the subducting panel results in the formation of two toroidal cells centred on the slab edges (Fig. 6, see also Funiciello et al., 2006; Husson et al., 2012). The pattern of mantle circulation is almost symetrical with (i) fast westward particle motion in the centre of the subduction zone with maximum velocities $\left(v_{\mathrm{h}(\mathrm{W}-\mathrm{E})} \approx 6 \mathrm{~cm} \mathrm{yr}^{-1}\right.$ ) (Fig. 6b), similar to the westward trench migration rate at the same period, (ii) fast eastward flow $\left(v_{\mathrm{h}(\mathrm{W}-\mathrm{E})}>4 \mathrm{~cm} \mathrm{yr}^{-1}\right)$ at the edges of the subduction zones (Fig. 6b).

The early stage of the subduction of continental lithosphere $(25 \mathrm{Myr})$ records variable trench migration rates along the trench (Fig. 3e, f). This directly affects horizontal velocities in the mantle with an asymetry in the westward particle motion between regions in front of the oceanic unit 

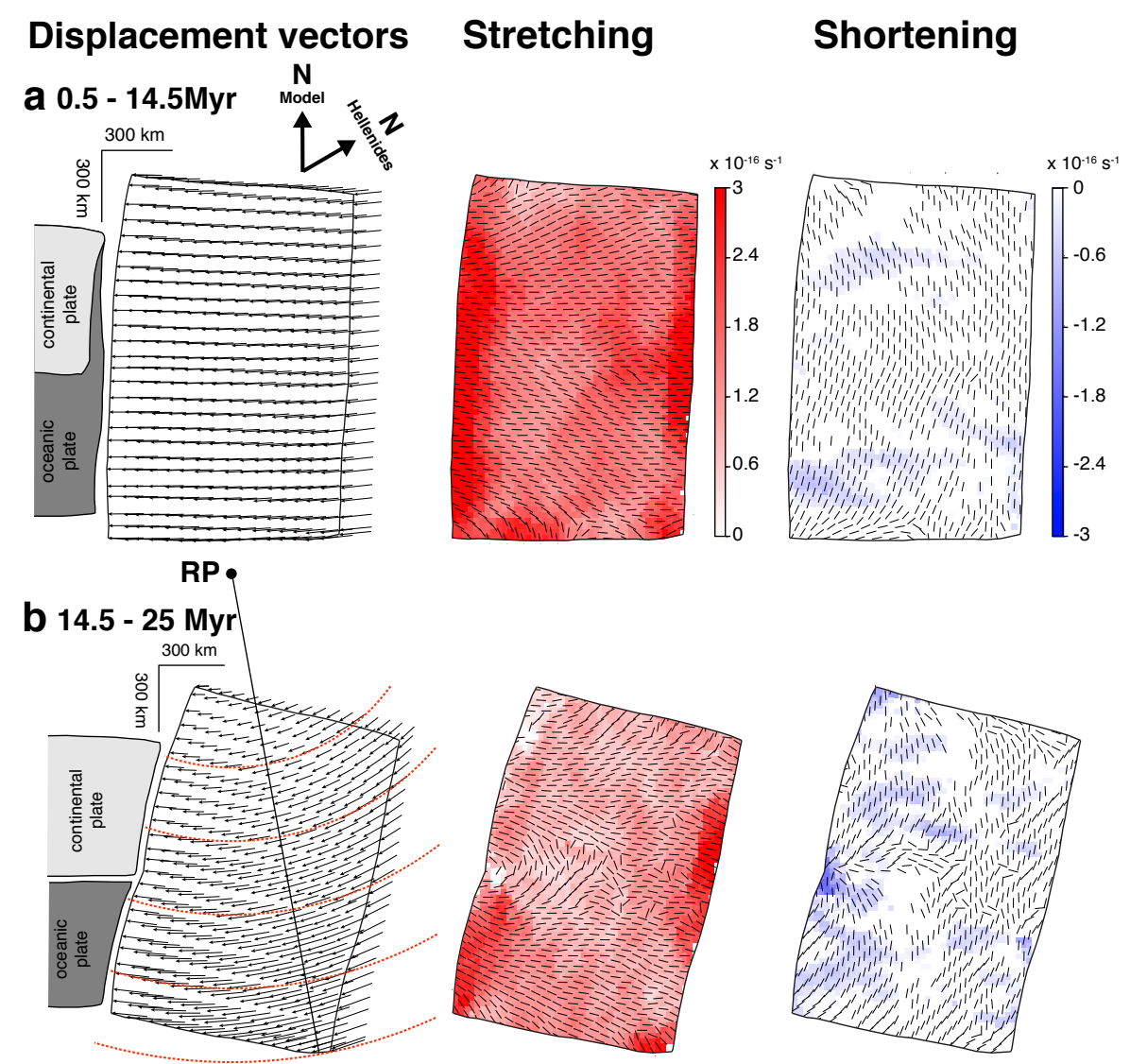

C 25 - 38.5 Myr
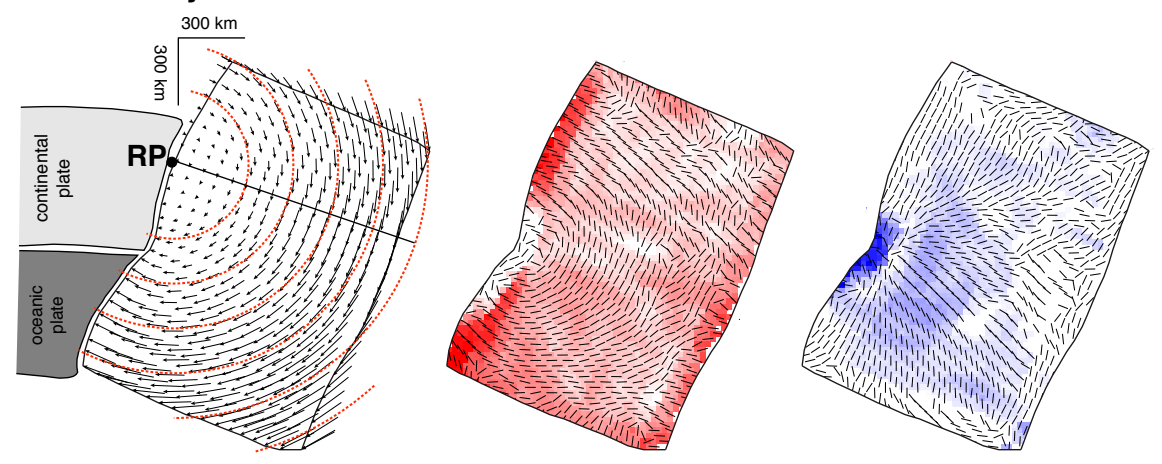

Fig. 7. Motion and deformation of the overriding plate for model 1, (a) between 0.5 and $14.5 \mathrm{Myr}$, (b) 14.5 and $25 \mathrm{Myr}$, and (c) 25 and 38.5 Myr after the initiation of subduction. Left panel shows displacements fields for each time interval. Central and right panels show the main directions and rates of stretching and shortening, respectively. RP is for rotation pole.

$\left(v_{\mathrm{h}(\mathrm{W}-\mathrm{E})}>4 \mathrm{cmyr}^{-1}\right)$ and in front of the continental unit $\left(v_{\mathrm{h}(\mathrm{W}-\mathrm{E})} \sim 2 \mathrm{cmyr}^{-1}\right)$ (Fig. 6b). Even if the surface involved in mantle flow has not significantly decreased with respect to the previous stage, the average motion of particle has slowed down both in the $\mathrm{W}-\mathrm{E}$ and $\mathrm{N}-\mathrm{S}$ directions owing to the overall decrease in trench migration rates (Fig. 6b, c).

After 40 Myr of subduction, a switch in mantle flow direction occurs in front of the continental unit, particles moving eastward at low velocities $\left(v_{\mathrm{h}(\mathrm{W}-\mathrm{E})}<0.5 \mathrm{~cm} \mathrm{yr}^{-1}\right)$ (Fig. 6b).
In front of the oceanic unit instead, the motion remains westward with maximum velocities at $\sim 4 \mathrm{~cm} \mathrm{yr}^{-1}$. In the mantle wedge just above the slab, mantle flow is mainly trenchperpendicular with fast motion for the oceanic unit whereas above the continental unit, it is mainly trench-parallel with low magnitude. Unfortunately, we could not monitor the models beyond that stage for technical reasons. 


\subsection{Overriding plate deformation}

We measure the horizontal strain within the overriding plate at different times of the experiment by tracking the displacement of grid nodes initially evenly-spaced by $60 \mathrm{~km}$. Owing to the newtonian behaviour of the silicone used to model the overriding plate, deformation is continuous. Figure 7 presents the displacement field and main strain directions recorded during three time intervals for model 1. Similar trench kinematics evolution were obtained for model 2 and 3, with two-times higher absolute trench velocities in the latter owing to the lack of overriding plate, and the same spatial pattern of deformation was recorded in model 2.

Before the arrival of continental lithosphere at the trench $(0.5-14.5 \mathrm{Myr})$, the finite displacement of the overriding plate with respect to the lower mantle reference frame is larger at its western edge than at its eastern edge, resulting in trench-perpendicular stretching (Fig. 7a). Stretching is not uniform, owing to differential basal shear tractions at the lithosphere-asthenosphere boundary resulting from heterogeneous mantle flow below the overriding plate. It is maximal within the first $120-180 \mathrm{~km}$ from the trench (Fig. 7a) and decreases away from the boundary. Local trench-parallel stretching at the southern and northern edges of the upper plate results from the free lateral boundary conditions that allow the silicone plate to spread laterally above the lowviscosity glucose syrup under the effect of gravity.

The early stage of continental lithosphere subduction $(14.5-25 \mathrm{Myr})$ is associated to a 30 to $60 \%$ decrease in trench retreat rates along the entire subduction zone (Fig. $3 \mathrm{~g}$, h). Its deformation decomposes into translation (herein irrelevant), plain rotation and stretching. During this period, the grid nodes rotate clockwise around a pole located $\sim 500 \mathrm{~km}$ north of the northernmost extent of the overriding lithosphere (Fig. 7b). Overriding plate mainly deforms through laterally non uniform stretching. For the first $180 \mathrm{~km}$ from the trench, trench-perpendicular stretching occurs in front of the oceanic unit about twice faster than in front of the continental unit $\left(\sim 3 \times 10^{-16}\right.$ vs. $\left.\sim 1.5 \times 10^{-16} \mathrm{~s}^{-1}\right)$. Region of maximum trench-perpendicular stretching coincides with the area where the gradient of the east-west component of horizontal mantle flow at the top of the asthenosphere is maximum (Fig. 6b), i.e. where shear stresses underneath the lithosphere are the highest. Within the first $60 \mathrm{~km}$ in front of the continental-oceanic transition, the overriding plate mainly deforms under moderate trench-parallel shortening (Fig. 7b).

In the final stage (25-38.5 Myr), the difference in alongtrench kinematics results in a clockwise rotation of grid nodes with a rotation pole located on the trenchward edge of the overriding plate in front of the continental unit (Fig. 7c). Despite the almost null motion of the trench at the location of the continental unit, the trenchward edge of the overriding plate north of the oceanic-continental transition still deforms under trench-perpendicular stretching at higher rates than recorded before $\left(>3 \times 10^{-16} \mathrm{~s}^{-1}\right)$ (Fig. $7 \mathrm{c}$ ). Deforma- tion here is controlled by stresses arising from the far-field, associated with trench retreat for the oceanic unit at moderate rates $\left(2 \pm 1 \mathrm{~cm} \mathrm{yr}^{-1}\right)$ (Fig. $\left.3 \mathrm{~g}, \mathrm{~h}\right)$. Within the first $60 \mathrm{~km}$ from the trench, the centre of the overriding plate is dominated by trench-perpendicular shortening (Fig. 7c). Indeed at this specific location, retreat of the oceanic lithosphere to the south triggers the westward absolute motion of the overriding plate at a faster rate than the westward absolute trench motion, slowed down by the subduction of positively buoyant lithosphere to the north. Beyond $120 \mathrm{~km}$, upper plate deforms under a combination of moderate stretching and shortening, the principal axis of stretching rotating from trenchperpendicular on its edges to trench-parallel in its centre (Fig. 7c).

\subsection{Dynamic topography}

Long-wavelength, non-tectonic uplift or subsidence counterbalance the vertical traction caused by the flowing mantle underneath the lithosphere. Ultimately, this flow is excited by density variations in the mantle, and that component of the topography is often referred to as dynamic topography (Ricard et al., 1984; Hager et al., 1985; Hager and Clayton, 1989; Cazenave et al., 1989; Mitrovica et al., 1989; Gurnis, 1993; Le Stunff and Ricard, 1995). Above the anomalies of the slabs, the amplitude of dynamic subsidence can exceed several hundred metres (Mitrovica et al., 1989; Gurnis, 1993; Zhong and Gurnis, 1994; Husson, 2006; Husson et al., 2012).

We track the vertical deformation of the model surface with a scanner during subduction in model 11 and in particular at the top of the asthenosphere above the subducting lithosphere, north and south of the discontinuity (Fig. 8). Because there is no overriding plate in this model, all the topography has a dynamic origin.

The subduction of buoyant material after $\sim 18 \mathrm{Myr}$ of subduction induces an instantaneous response of the surface for the northern continental subduction zone with an uplift of around $0.7 \mathrm{~km}$ in $\sim 3 \mathrm{Myr}$ at $250 \mathrm{~km}$ from the trench (Fig. 8b). Conversely, in the oceanic portion of the subduction zone, although the trench retreat velocity strongly decreases, the variations in surface elevation remain elusive during $\sim 10 \mathrm{Myr}$ (Fig. 8c). However, between 30 and $42 \mathrm{Myr}$, the surface uplifts by $\sim 0.7 \mathrm{~km}$, which may be explained by the influence of positively buoyant material to the north, that globally decreases the subduction rate, and as such, the vertical traction exerted by the mantle on the surface. Surface motion at $500 \mathrm{~km}$ from the trench appears insensitive to changes in slab buoyancy (Fig. 8b, c). However, on the long-term, the surface gently uplifts at rates of $\sim 0.02 \mathrm{~mm} \mathrm{yr}^{-1}$ for both continental and oceanic subductions between 18 and $42 \mathrm{Myr}$. Dynamic topography being directly sensitive to the vertical component of mantle flow, it once more reflects the fact that during that time interval the vigor of the horizontal mantle flow has decreased (Fig. 6), but also the vertical traction 


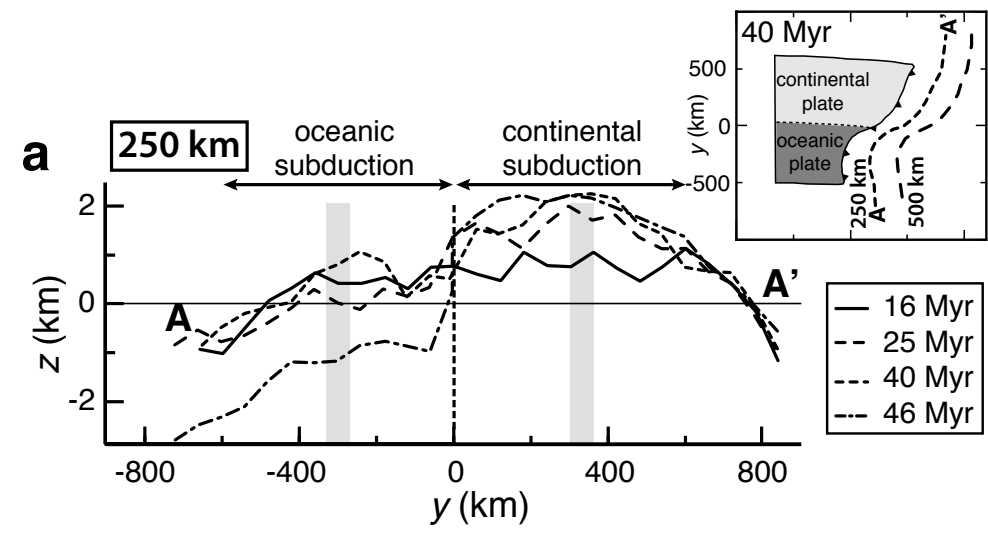

\section{b Continental subduction}
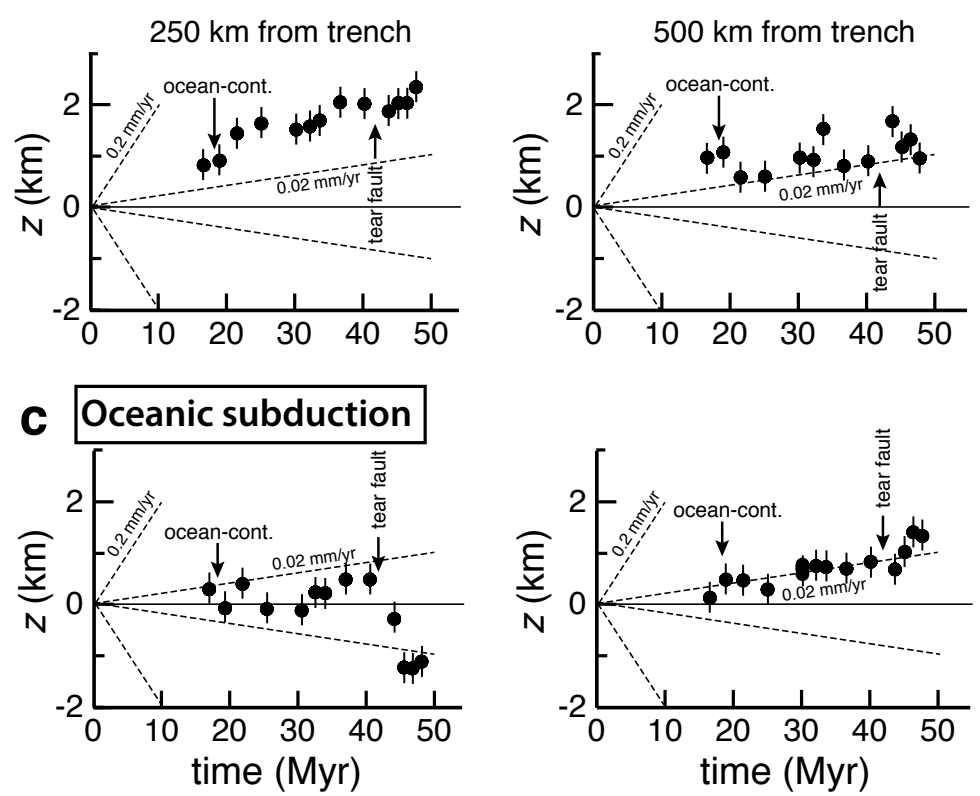

Fig. 8. (a) Dynamic topography measured at the surface of the asthenosphere for model 11 at a distance of $250 \mathrm{~km}$ from the trench after 16 , 25,40 and $46 \mathrm{Myr}$ of subduction. Inset indicates the location of cross-sections at 250 and $500 \mathrm{~km}$ from the trench after $40 \mathrm{Myr}$ of subduction. (b) Time-evolution of dynamic topography for the same model above the centre of the continental subduction zone at $250 \mathrm{~km}$ from the trench (left panel) and $500 \mathrm{~km}$ from the trench (right panel). Elevations are averaged on a $60 \mathrm{~km}$ wide trench-perpendicular swath to remove any shorter wavelength perturbations (see position of swath on Fig. 8a). (c) Same as (b) for the oceanic subduction. Trends for uplift and downlift velocities of 0.02 and $0.2 \mathrm{mmyr}^{-1}$ are indicated by dashed lines.

underneath the surface as a result of the overall decrease in slab buoyancy.

After $42 \mathrm{Myr}$, the tear fault decouples the continental and oceanic units, which strongly modifies the dynamic topography above the oceanic portion of the subduction zone. A $1.7 \mathrm{~km}$ downlift of the surface is recorded at $250 \mathrm{~km}$ from the trench, yielding a subsidence rate of $\sim 0.3 \pm 0.1 \mathrm{~mm} \mathrm{yr}^{-1}$ (Fig. 8c). Decoupling the two slab segments results in a lesser reciprocal influence, in the sense that the kinematics no longer correspond to an average buoyancy of some kind. The narrow oceanic slab unit then subducts at its proper rate, faster than the initial rate that corresponds to a wide slab.
Subduction becomes more vigorous, and dynamic topography exceeds by $1000 \mathrm{~m}$ its initial value, prior to the entry of the continental unit into the subduction zone. This additional $1 \mathrm{~km}$ downlift is therefore a consequence of mantle flow reorganisation associated to slab narrowing, which in this case promotes faster vertical sinking of the slab. 

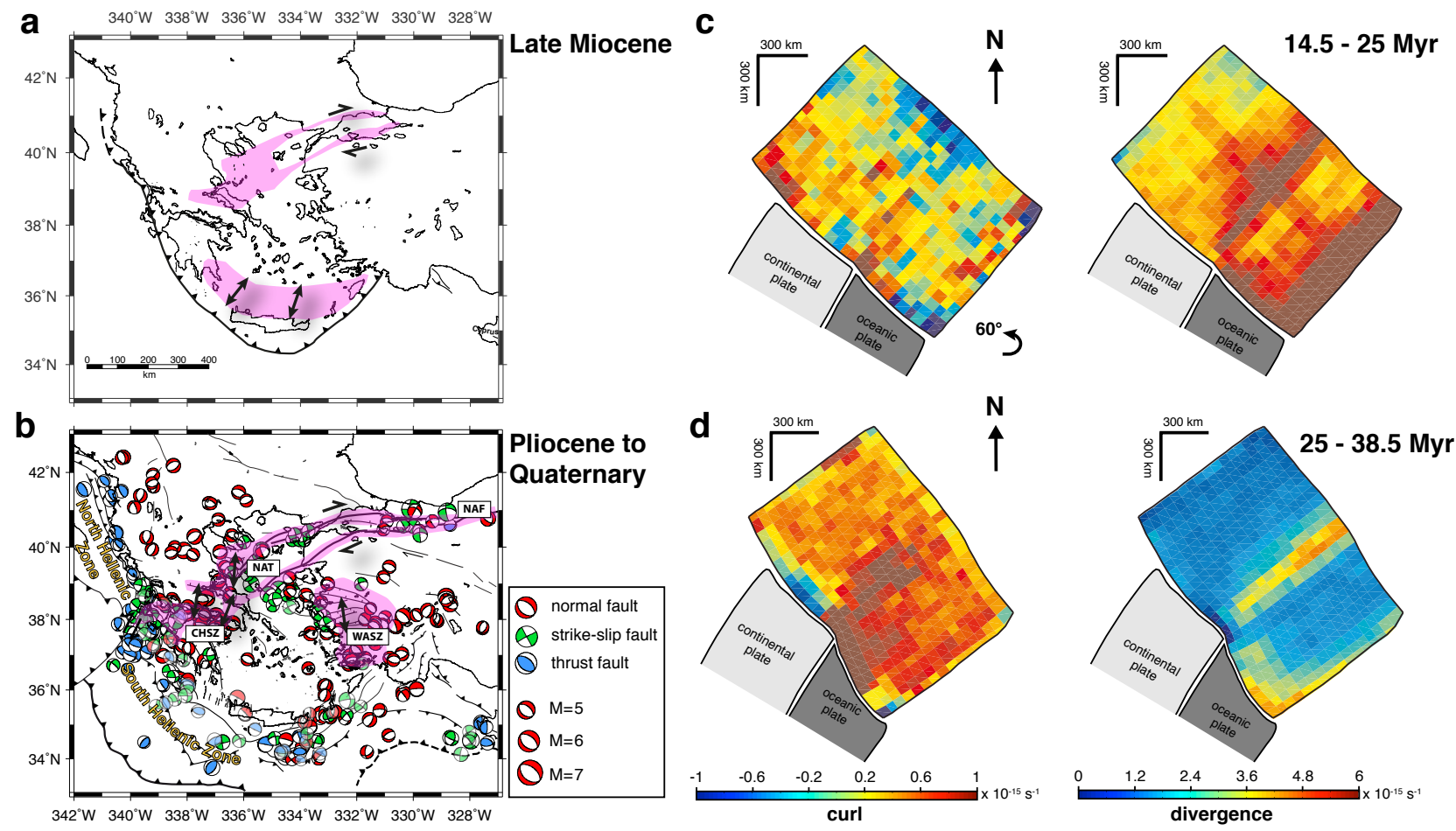

Fig. 9. Upper plate deformation within the Aegean region for (a) the Late Miocene and (b) Pliocene to Quaternary periods (after Royden and Papanikolaou, 2011; Jolivet et al., 2013). The approximate areas affected by extension and/or strike-slip activity for the considered time period are indicated in pink (deformation is not palinspastically restored) and the main active structures and focal mechanisms of earthquakes at depths lower than $50 \mathrm{~km}$ (source: CMT, 2011) are shown in (b). Earthquakes with depths between 30 and $50 \mathrm{~km}$ are indicated with transparent beachballs. (c) Curl (left panel) and divergence (right panel) computed from the overriding plate horizontal displacement field for the 14.5-25 Myr time period of model 1. (d) Same as (c) for the 25-38.5 Myr time period. A $60^{\circ}$ counterclockwise rotation has been applied to panels (c) and (d) to make the trench orientation fit the orientation of the Hellenic trench.

\section{Comparison to the Hellenic subduction}

\subsection{Geological setting}

The Hellenic subduction is a small remnant of the vast Tethyan subduction that drove the collision of Africa and Eurasia (Fig. 1). Another few of those small subduction zones are found in the Mediterranean (e.g. Royden, 1993; Malinverno and Ryan, 1986), but the Aegean slab is probably the last that remains powerful enough to be considered an active tectonic system, for the subducting Ionian lithosphere could be the oldest seafloor on Earth (Speranza et al., 2012). In the general framework of the now very slow AfricanEurasian collision, the subduction of the Aegean slab, that is attached to Africa, resembles the fixed mode of subduction of our models. Fast rollback accompanied the subduction, triggering pervasive lithospheric extension in the Aegean domain (see Jolivet et al., 2013, for a review), trenchward migrating volcanism and exciting adjacent mantle flow (Paul et al., 2010).

However, this activity did not prevail throughout the entire Tertiary (e.g. Papanikolaou and Royden, 2007; Brun and Sokoutis, 2010; Royden and Papanikolaou, 2011; Jolivet et al., 2013). The Aegean domain globally spreads until MidMiocene, until the right lateral North Anatolian Fault (NAF) isolated Anatolia from the Eurasian continent (Šengör et al., 2005; Royden and Papanikolaou, 2011), cut through the Marmara Sea and reached the Aegean Sea and formed the North Aegean Trough (NAT). During that early stage, lithospheric stretching accommodated slab retreat and faults trended parallel to the uniformly retreating trench.

Then, a brief Late Miocene to Early Pliocene episode of localised arc parallel extension occurred in the outer rim of the Hellenic arc, in the Cretan Sea and Peloponnese in particular (Fig. 9a). This event is coeval to the inception of the right lateral Kefalonia Fault (Papanikolaou and Royden, 2007) which, from Pliocene onwards, further modified the kinematics of the area. The subduction of a plate of laterally variable buoyancy along the Hellenic trench could have profoundly modified the Aegean dynamics. Indeed, since Late Miocene times, the Kefalonia Transform Fault isolates the Adriatic continental unit from the Ionian oceanic plate (Kahle et al., 1993; Vassilakis et al., 2011). Subduction rates at the North and South Hellenic trenches occur at rates of 5 to $12 \mathrm{mmyr}^{-1}$ and 25 to $40 \mathrm{~mm} \mathrm{yr}^{-1}$ (e.g. McClusky et al., 


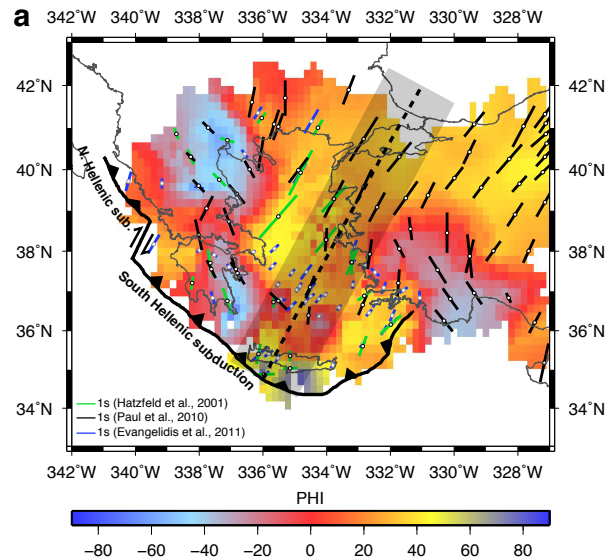

b

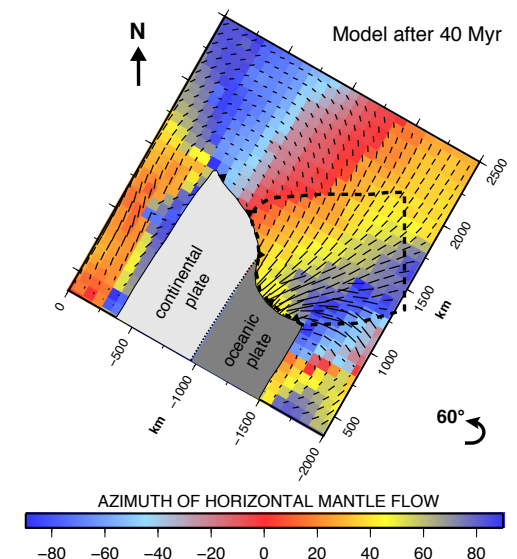

C

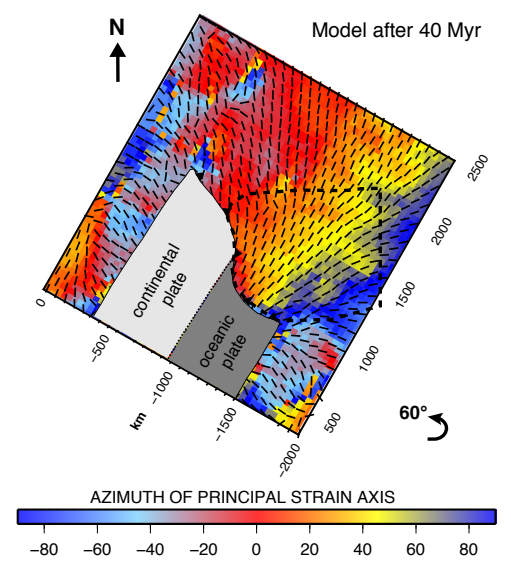

Fig. 10. (a) Azimuth (interpolated, colourscale) and delay (bars) of seismic anisotropy in the Aegean-Anatolian region obtained from SKS waves (green bars, Hatzfeld et al., 2001; black bars, Paul et al., 2010; blue bars, Evangelidis et al., 2011). (b) Azimuth of horizontal mantle flow for model 11 after $40 \mathrm{Myr}$ of subduction. Black bars indicate the direction and relative magnitude of mantle flow. The black dashed lined underlines the approximate corresponding region of SKS data shown in Fig. 10a. (c) Azimuth of the principal strain axis for model 11 after $40 \mathrm{Myr}$ of subduction. Black bars indicate the direction of principal strain component. A $60^{\circ}$ counterclockwise rotation has been applied to panels (b) and (c) to make the trench orientation fit the orientation of the Hellenic trench.
2000; Royden and Papanikolaou, 2011; Pérouse et al., 2012), respectively, which offsets the South and North Hellenic subduction zones by a few tenths of kilometres at present day. The formation of the fault itself results from the entry in the subduction zone of a very negatively buoyant oceanic plate to the south, while in the north the subduction of a continental unit of increasingly positive buoyancy proceeds, as the buoyancy difference of the two plate units suffices to trigger a laterally variable regime along the trench (Royden and Papanikolaou, 2011). P- and S-wave velocity perturbations show that the subducted crusts for two sections north and south of the Kefalonia Fault are dextrally offset, implying an additional $\sim 70-85 \mathrm{~km}$ retreat of the southern segment of the slab (Pearce et al., 2012).

The Aegean Sea then migrated along with the trench to the southwest (with respect to stable Eurasia), as an apparently almost rigid unit (McClusky et al., 2000; Kreemer and Chamot-Rooke, 2004). Extension is now focussed in the West Anatolian Shear zone (WASZ), on the western margin of Turkey, in the Peloponnese and in Mainland Greece (Gautier et al., 1999; Jolivet et al., 2013; Royden and Papanikolaou, 2011, Fig. 9b). Only in Mainland Greece and Peloponnese deformation remains somewhat diffuse (Vassilakis et al., 2011; Bradley et al., 2013); only in this area the Anatolian plate is not separated from Eurasia by a discrete right lateral fault. The Kefalonia Fault could be linked to the North Anatolian Fault via the diffuse transtensional Central Hellenic Shear zone (CHSZ) (Royden and Papanikolaou, 2011) that separates the Peloponnese from Mainland Greece (Fig. 9b). In this area, normal faults, including the Corinth Rift, developed obliquely to the trench. From north to south, faults trend $\sim \mathrm{N} 90$ in Mainland Greece, gently swing to $\sim$ N120 across the Gulf of Corinth, and reach $\sim$ N170 (approximately trench parallel) in the South Peloponnese (e.g. Doutsos, 2001). From the western tip of the NAF to the Kefalonia Fault (i.e. in the NAT and CHSZ), only normal faulting is unequivocally identified; this lead Pérouse et al. (2012) to advocate that the GPS inferred strain field does not require any dextral shear component in this area.

Despite the inherent oversimplifications of our experimental setup, our dynamic models resemble the Hellenic subduction by many aspects. The Kefalonia Fault shall be considered as the tear fault (possibly shear-stress free) that begins to isolate plate units of contrasted buoyancies, as in the early stages of our models. In the following, we interpret the observables for the Hellenic subduction (trench and upper plate kinematics, mantle flow and topography) at the light of our dynamic models.

\subsection{The Hellenic trench}

The Hellenic trench initially migrated continuously along the outer rim of the Aegean domain. It accompanied the global expansion and spreading, that is well reproduced by our models, where the initially linear trench becomes concave during 
trench retreat (Fig. 4), as in earlier models (e.g. Funiciello et al., 2003; Morra et al., 2006; Loiselet et al., 2009). The shape of the trench responds efficiently to the entry of a plate of laterally variable buoyancy into the subduction zone. In the models, it corresponds to the introduction of a low buoyancy unit that locally decreases the trench migration rates (Fig. 3); in the Hellenides it is the introduction of the old Ionian oceanic lithosphere after the consumption of the Adria block that speeds up trench migration to the south. In both cases, the difference in trench migration rates imposed by lateral slab buoyancy variability increases by a few tenths of $\mathrm{mm} \mathrm{yr}^{-1}$ after a few million years. It is accompanied, in the models, either by a viscous shear of the subducting plate when no built-in tear fault accommodates the differential trench motion, or by a right lateral slip along the tear fault when present (Fig. 4). This setting is akin to the Kefalonia Fault, and we confirm that it is this mechanism that excites the Kefalonia Fault and that offsets the margin of the overriding plate by some $\sim 100 \mathrm{~km}$ at a rate of $\sim 14$ to $25 \mathrm{~mm} \mathrm{yr}^{-1}$ (Vassilakis et al., 2011; Royden and Papanikolaou, 2011). This value corresponds to the difference in the trench velocities of the northern and southern Hellenic subduction zones, a figure that is also obtained in the models after a few million years (Fig. 3). Interestingly, the models show that it takes more than $\sim 4 \mathrm{Myr}$, i.e. the time since the onset of the activity of the Kefalonia Fault, before steady state is reached. This suggests that the slip rates along the Kefalonia Fault may be accelerating and continue to speed up in the future (along with an acceleration of the southern trench migration, as also shown by Royden and Papanikolaou, 2011).

Trench depth varies along strike; while in the Northern Hellenides the trench is shallower than $\sim 1000 \mathrm{~m}$, in the southern counterpart, it is more than $3000 \mathrm{~m}$ deep (Fig. 11). The absolute trench depth in the models overshoots that figure by 5000 to $8000 \mathrm{~m}$ (Fig. 5b, c, and Husson et al., 2012), because our setup does not account for faults (as in Zhong and Gurnis, 1994, for instance), and because the meniscus caused by surface tension increases the depth by a constant. Those undesired effects are particularly high at low rates. However, relative depths for similar subduction rates are comparable in our models (Fig. 5c), i.e. some 2000 to $4000 \mathrm{~m}$ deeper for fast subducting plates (at $\sim 30 \mathrm{~mm} \mathrm{yr}^{-1}$ ) than for the slowly subducting plates (at $\sim 10 \mathrm{~mm} \mathrm{yr}^{-1}$ ). This results confirms that the along strike variations in the Hellenic trench depth mirror the laterally variable subduction rates. Yáñez et al. (2004) found similar results for the Andean subduction, i.e. trench depth is controlled by convergence rate but also by interplate coupling.

\subsection{Aegean deformation}

Trench migration in our models follows the mechanism that was initially proposed by Royden and Papanikolaou (2011). In addition, our models explore the impact of the inception of the Kefalonia Fault onto the upper plate. Silicone plates be- have as quasi-Newtonian fluids at experimental strain rates. Thus, in our simplified model, upper plate deformation is diffuse and the models do not produce any of the faults that may also accommodate deformation of the overriding lithosphere in nature. In addition, strength layering that may produce significant deformation partitioning over the lithosphere thickness is not accounted for. However, upon the assumption that the brittle crustal deformation is a surface expression of the overall viscous lithospheric deformation, the firstorder comparison between the continuous deformation of the models to the discrete deformation observed on Earth holds. Indeed, our models show comparable patterns of deformation and may explain the temporal evolution of Aegean tectonics though, of course, the diffuse deformation and the unaccounted Anatolian extrusion prevent the reproduction of the discrete dextral shear found in the NAT and NAF.

During the early stage of Aegean expansion, prior to the inception of the Kefalonia Fault, lithospheric stretching accommodated slab retreat and faults trended parallel to the uniformly retreating trench, in agreement with the deformation seen during the early stages of our models: extension is widespread and reaches its fastest rate on the entire plate (Fig. 7a). The inception of the tear fault initiated a nonuniform rollback and trench migration (see Sect. 4.2) that caused a wholesale rotation of the upper plate around a Euler pole located some $1200 \mathrm{~km}$ from the triple junction (Fig. 7b). Deformation remained essentially extensional, and the deformation axis in the models show that normal faults in front of the oceanic unit are expected to trend parallel to the trench (Fig. 7b). This episode explains the arc parallel "transitional" episode of deformation of Papanikolaou and Royden (2007) (Fig. 9a).

The third stage of deformation (Fig. 7c) occurs at the time where the tear fault reaches mantle depths. Then, the Euler pole shifts to a much closer location to the triple junction between the tear fault and the trench, at $\sim 300 \mathrm{~km}$. It approximately matches the location of the Euler pole for postEocene (and probably post-Oligocene) rotations that was found close to Scutari-Pec, Albania, on the basis of paleomagnetic measurements (Speranza et al., 1992). It is similar to the Euler pole proposed by van Hinsbergen et al. (2005) on the basis of paleomagnetic measurements for western Greece, on average since Mid-Miocene (thus compatible). It also matches the location of the Euler pole found by Brun and Sokoutis (2010), on the basis of a comparison between stretching lineations and seismic anisotropy; however, these authors reach slightly contrasting conclusions, for they suggest that the location of the pole has remained stationary for the last $45 \mathrm{Myr}$, while our models suggests it may have only began since the onset of the Kefalonia Fault. The rotation pole in our model is also a little further from the rotation pole proposed by Pérouse et al. (2012) from kinematic indicators. That rotation is accompanied by strong extension in the vicinity of the trench. In the models, the extension axis is approximately oriented $\mathrm{N}-\mathrm{S}$ in front of the triple junction, 
at an equivalent location to the CHSZ (Fig. 7c). The two last stages therefore reproduce the structural pattern of the Peloponnese and Mainland Greece, where extension shifts from arc-parallel to arc-crossing trends. In particular, the $\sim \mathrm{EW}$ trending Corinth rift is well explained by our models. In addition, our models predict some localised compression next to the triple junction (Fig. 7c), a somewhat less abundant, yet present, feature in Greece around Kefalonia (Sachpazi, 2000; Vassilakis et al., 2011, and Fig. 9b).

A synthetic view is given by the horizontal divergence and curl of the model surface velocity fields (Fig. 9c, d), that we use to locate stretching and shear, respectively. After the first stage of widespread extension, the divergence field reveals the initiation of an elongated extensional zone in front of the triple junction during the second stage (after the inception of the tear fault) (Fig. 9c), i.e. at a location that compares to that of the CHSZ and NAT with respect to the Kefalonia Fault; this episode continues during the third stage, but decreases in magnitude (Fig. 9d). Furthermore, divergence in this area indicates that the extensional zone in our models enlarges and increases in magnitude north-eastward, away from the triple junction, i.e. at comparable location to the NAT. This pattern of scissors-like stretching is that of the deformation from the Gulf of Patras towards the Aegean sea. A second zone of extension appears by the oceanic trench, at a location that compares to that of the Cretan Sea and Peloponnese, a feature that decreases during the third stage, in accordance with the geological record. Second, mapping the curl of the horizontal velocity field locates occurrences of toroidal flow, that is the local rotation about the vertical axis, that we interpret as the location where strike slip faulting is expected (Fig. 9c, d). The curl shows that very little shear occurs during the second stage, but seriously increases during the third stage. Besides the strong shear that the models show immediately adjacent to the trenches (dextral next to the oceanic unit, sinistral by the continental unit), dextral shear is found on a band that branches onto the triple junction, normally to the trench, that narrows eastward. It is largest close to the trench, at a location that compares to that of the wide CHSZ with respect to the Kefalonia Fault. It thins away at a location that matches that of the narrow NAT and NAF, as opposed to divergence. In summary, deformation evolves through time from extension towards strike-slip via transtension, as indicated by the ratio divergence/curl that decreases through time, by an average factor of $\sim 4$ from the second to the third stage. As dextral shear builds up, the deforming zones narrow, which resembles the evolution of the broad extensional NAT, Cretan Sea and Peloponnese (during Late Miocene and Early Pliocene, i.e. the second stage) towards a more localised dextral transtension across the CHSZ and NAT (during the third, Plio-Quaternary stage), as suggested by Papanikolaou and Royden (2007). This resemblance lead us to conclude that together, the divergence and curl fields of the model horizontal velocities clearly predict the deformation field as revealed from structural analysis (Papanikolaou and Royden, 2007), but also from the focal mechanisms at present-day (Fig. 9b). In details, eastward from Kefalonia, observed deformation shifts from (dominantly) compression to (dominantly) dextral strike slip and (dominantly) extension around Corinth. Our models successfully reproduce the observed kinematics, with a late episode of $\sim$ N50 trending dextral shear (akin to the NAT and NAF) and $\sim$ N90 trending normal faults (akin to the Gulf of Corinth) that follows a transitional episode of arc parallel normal faulting. The dynamic causes shall be explored from the analysis of the mantle flow.

\subsection{Mantle flow}

The three stage tectonic evolution of the Hellenic domain is successfully reproduced by our models; they correspond to the subduction of uniformly buoyant slab, to the entry of the heterogeneous slab, and last, to the complete subduction of the tear fault. How it forces the deformation of the upper plate is due to the changes in the driving forces, and it is in the mantle that they vary most efficiently during transient subduction. Significant insight for this comes from the fact that the curl does not show any influence of the incipient Kefalonia Fault until the tear fault reaches mantle depth and modifies the underlying mantle flow; this suggests that it is mostly mantle drag that efficiently controls the kinematics of plate boundaries (Husson, 2012).

At present-day, the Hellenic slab is most likely torn between Rhodes and Cyprus and a window allows for mantle flow underneath West Anatolia (Govers and Wortel, 2005). The situation is less clear for the Kefalonia Fault; seismic tomography (Spakman et al., 1988; Piromallo et al., 2006; Suckale et al., 2009) possibly reveals a discontinuous slab and more detailed seismic experiments suggest that the surface of the slab is offset horizontally by some $100 \mathrm{~km}$ across the Kefalonia Fault (Gesret et al., 2011). However, whether the mantle flows through a potential Kefalonia window remains uncertain, and it is most likely small, if any. Only seismic anisotropy (Fig. 10a, Paul et al., 2010; Hatzfeld et al., 2001; Evangelidis et al., 2011) possibly advocates for alongarc mantle flow that could be interpreted as originating from the Kefalonia window, but the not-so-clear nature of alongarc anisotropy (e.g. Russo and Silver, 1994; Long and Silver, 2009; Faccenna and Capitanio, 2013) prevents from being conclusive. Overall the trend of seismic tomography in the sublithospheric mantle does not accurately match the motion of Anatolia. In particular, anisotropy is not imprinted yet by the too young shear underneath the North Anatolian fault (Kreemer et al., 2004; Jolivet et al., 2009); this observation precludes its use as a mean to explore recent changes in mantle deformation.

However, based on the comparison to surface deformation, Pérouse et al. (2012) concluded that the Kefalonia window is opened. Indeed, surface strain shows what Pérouse et al. (2012) refer to as two toroidal cells, dextral and sinistral at the western and eastern edges of the oceanic slab. Our models 
show that this behaviour is also obtained just before the actual opening of the tear fault (Fig. 7c). However, our models also showed that it is only when the tear fault is actually subducted that dextral shear appears. Although our main conclusions hold, this contradicts the interpretations of Pérouse et al. (2012) on the timing of events. Our models show that the onset of differential motion between the two units leads to a more vigorous mantle flow in the oceanic section than in the continental section, which induces dextral shear in the overriding plate. This shear only happens when the diversion of the mantle flow because of the Kefalonia tear fault begins, and not before (when the fault has not reached mantle depths). If the slab window was fully opened, and allowed for mantle flow through it, dextral shear would be even more dramatic. This shows that it is mantle flow, and not trench pull or any shallow process, that causes it. Instead, we conclude that the increasingly vigorous toroidal flow around the edges of the oceanic slab is responsible for dextral shear across the two units: basal, southwestward drag grows larger in the southern section than in the northern one and is enough to shear the overriding plate, possibly helping the NAF to make its way across the Aegean and Mainland Greece and Peloponese.

\subsection{Dynamic topography}

Mantle flow induces vertical tractions that deflect the surface. Mantle flow models indicate that dynamic topography is likely in excess of $1000 \mathrm{~m}$ in the Cretan Sea (Husson, 2006; Boschi et al., 2010; Faccenna and Becker, 2010). In particular, it may be responsible for the very deep Cretan Sea (Fig. 11). Of course, residual topography is not real topography. Nevertheless, we note that in the Aegean domain, crustal thickness only varies by a few kilometres (e.g. Tirel et al., 2004) and isostasy by no means shall suffice to explain the $\sim 2000 \mathrm{~m}$ variations in elevation. Indeed, elevation drops from north to south across the CHSZ, from the continental North Hellenic subduction to the oceanic South Hellenic one (Fig. 11). Second, flooding of the Aegean sea started after rollback started (see the paleogeographic reconstructions of Dermitzakis and Papanikolaou, 1981) and likely increased during Late Neogene (Wright, 1978; van Hinsbergen et al., 2004, 2005). It remains difficult to evaluate the subsidence rates, but we observe that subsidence therefore took place above the oceanic slab, at the time during which its purported negative buoyancy increased (Royden and $\mathrm{Pa}-$ panikolaou, 2011). These observations match our model results (Fig. 8) that predict an increasing difference in elevation between the two units. This result corroborates the idea that dynamic topography plays a critical role in shaping the Aegean seafloor. a
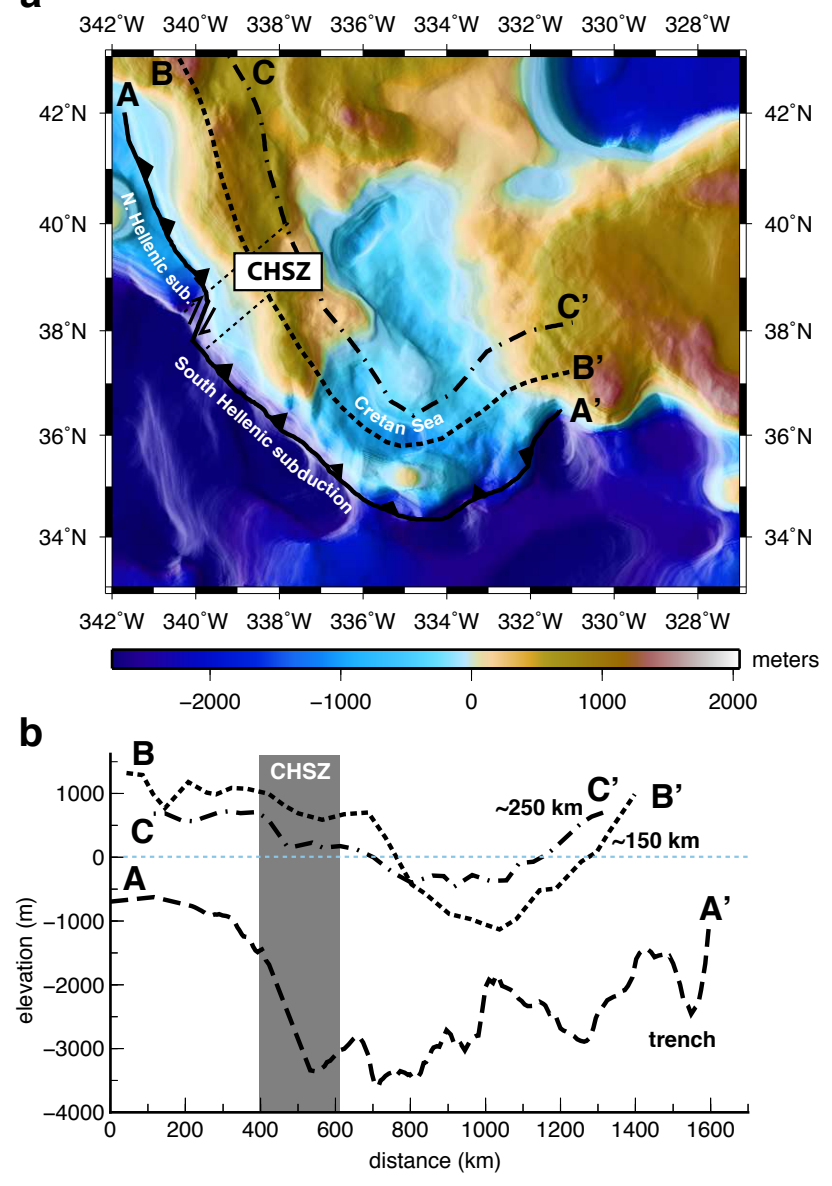

Fig. 11. (a) Smoothed topography of the Aegean region. ETOPO1 global topography (Amante and Eakins, 2009) has been filtered with a $150 \mathrm{~km}$ large median filter using Generic Mapping Tools (Wessel and Smith, 1998). (b) Topographic profiles of the trench (A$\mathrm{A}^{\prime}$; dashed line) and of the Aegean overriding lithosphere at a distance of $\sim 150 \mathrm{~km}\left(\mathrm{~B}-\mathrm{B}^{\prime}\right.$; dotted line $)$ and $\sim 250 \mathrm{~km}\left(\mathrm{C}-\mathrm{C}^{\prime}\right.$; dasheddotted line) from the trench.

\section{Discussion and conclusions}

We use three-dimensional analogue models of subduction to explore the interplay between mantle flow and surface tectonics during the subduction of a slab of laterally variable buoyancy. The simplified experimental setup provides the necessary ingredients to successfully reproduce the kinematics and tectonic history of the Aegean-Anatolian region since middle Miocene and for the analysis, in particular, of the role played by mantle flow around the Kefalonia Fault.

For a fixed ridge configuration, slab pull controls the subduction velocity, which essentially scales with trench velocity. Lateral density variations modify this simple scaling law and cause a profound, three-dimensional reorganisation of the subduction system. Trench migration rates are not only controlled by the local slab pull force, but are also 
influenced by the changes in neighbouring slab density. This is the case of the Hellenic subduction zone, where the buoyancy of the subducting lithosphere purportedly drastically changes across the Kefalonia Fault, from a dense oceanic to a continental lithosphere. In all models, trench migration rates within the oceanic unit decreases after the onset of continental unit subduction despite the unchanged local slab pull force. The influence is gradual and vanishes at larger distances than $\sim 500 \mathrm{~km}$ from the density discontinuity. The reciprocal effect, that would be trench retreat for the continental unit despite the low or null local slab pull force, is not verified. Instead, trench stops retreating in spite of the still active local slab pull force. This illustrates the three-dimensional effect, which is the role played by the toroidal flow underneath the continental plate, excited by the adjacent fast retreating oceanic plate. Compressive stresses underneath the slow-retreating continental unit cause it to prematurely stall and even advance. Geological observations seem to indicate that the Cretan portion of the trench migrated substantially further to the south and southwest than did the Peloponnesus portion of the trench from Middle to Late Miocene onwards (Royden and Papanikolaou, 2011), illustrating the decreasing trench retreat rates in Peloponnesus due to the subduction of more buoyant material beneath the northern Hellenides. Our analysis also shows how mantle flow is controlled by changes in along-trench kinematics. During the subduction of a uniform slab, trench retreat is almost uniform along the entire length of the subduction zone and two symmetrical toroidal cells develop at the edges of the subduction zone. In the Central Mediterranean, such mantle flow pattern has been proposed to explain for instance anomalous uplift around the Calabrian subduction zone (Faccenna et al., 2011). A direct comparison with the Hellenic subduction zone at this stage is more hazardous since only one slab tear between the western edge of the Cyprus slab and the eastern edge of the Hellenic slab is clearly imaged by tomographic models (e.g. Salaün et al., 2012). The following stages instead more likely resemble the Hellenic subduction zone with the introduction of a lateral buoyancy variation, similar to the difference in slab buoyancy across the Kefalonia region, that diverts horizontal mantle flow from its previous symmetry. Toroidal flow through the western Anatolian slab window, as imaged by SKS splitting data (Paul et al., 2010), results here from the fast retreat of the oceanic unit in the southern portion of the subduction zone. The latter is also responsible for trenchparallel mantle deformation north of the discontinuity, that could be one explanation for the NW-SE direction of fast polarisation of SKS data observed beneath Mainland Greece (Fig. 10). However, strain calculated in the model is shortterm (calculated over a $0.5 \mathrm{Myr}$ period) whereas fast direction of SKS data most likely reflects the long-term deformation of the mantle beneath the Aegean-Anatolian region. In addition, interpreting trench-parallel direction of SKS data close to the trench is not trivial (e.g. Long and Silver, 2009).
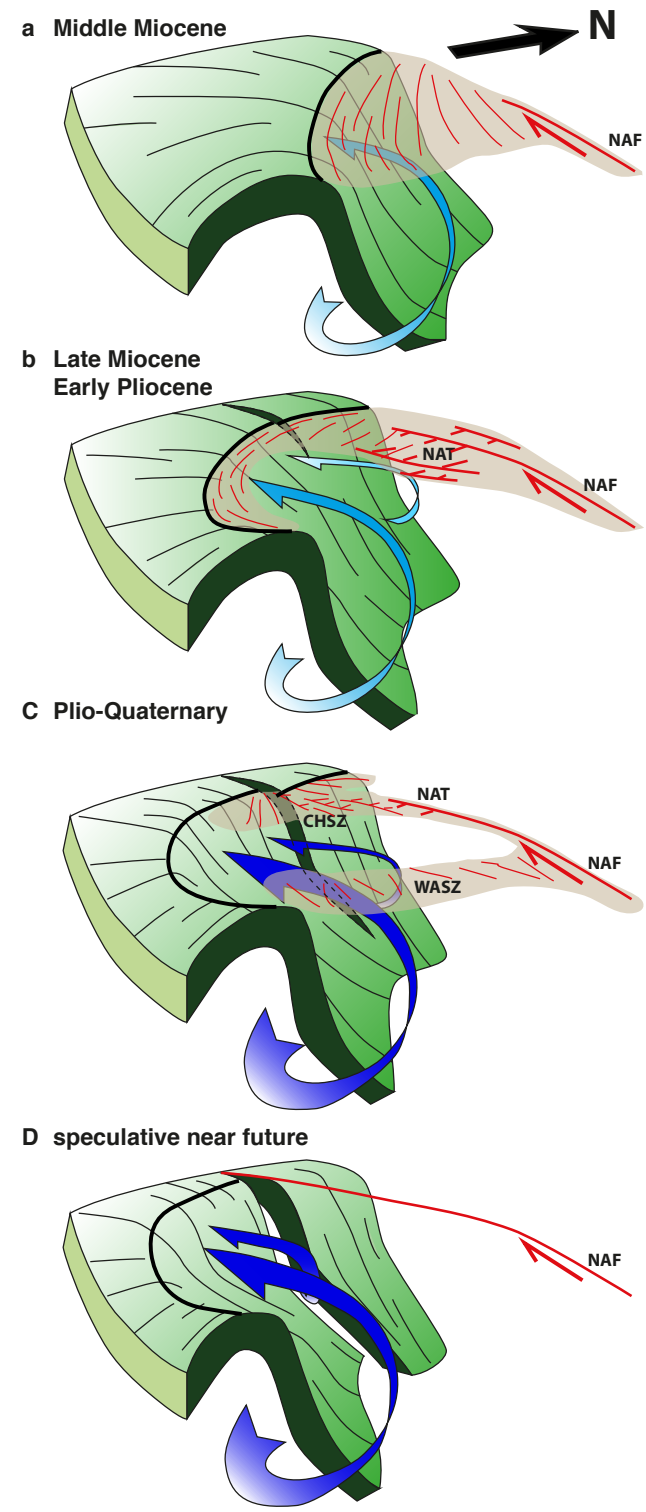

Fig. 12. 3-D sketches (redrawn after Jolivet et al., 2013) showing middle Miocene to present-day evolution of slab geometry, mantle flow and overriding plate deformation in the Aegean-Anatolian regions and speculative interpretation of their evolution in the near future on the basis of outputs from the three-dimensional dynamic models.

Because of their simple setups, our models reveal the main lines of the dynamic events that drove the tectonics of the Aegean domain. It allows to disentangle competing mechanisms and to interpret the geological history of the Aegean. We interpret the three stages of deformation that are recognised from the geological record by a first stage of subduction of a uniformly buoyant plate that only lead to the global expansion of the Aegean domain during MidMiocene (Fig. 12a). This was followed by a Late MioceneEarly Pliocene transitional stage during the inception of the 
Kefalonia Fault (Fig. 12b). This event initiated the disruption of the chiefly poloidal flow underneath the Aegean. The Aegean plate got dextrally sheared because of the underlying mantle flow, while arc-parallel normal faulting prevailed in the outer rim of the Aegean. From Pliocene onwards, the ongoing subduction of the Kefalonia tear fault increased the differential rollback between the two units (Fig. 12c). Dextral shear along the CHSZ grew stronger because of the underlying mantle that flowed at fast rates in the South while in the North it only got sucked by the adjacent oceanic plate, in a toroidal mode. Deformation became chiefly transtensional, because of the closer location of the Euler pole to the triple junction. It is because of this transitional regime that normal faulting started in the Corinth Rift. In our models as in nature, the differential motion across the Kefalonia Fault is $\sim 20 \mathrm{~mm} \mathrm{yr}^{-1}$. When the tear fault operates at mantle depth, this is also the range of difference in trenchward mantle flow rates. We emphasise that this is mantle flow, and not trench pull or any shallow process, that helped localising deformation along the narrowing CHSZ and NAT, which occurred only when the tear fault separating the continental and oceanic units reached mantle depths.

Because the tear fault is not entirely subducted and the slab window is only beginning to open, the difference in trench velocity across the Kefalonia Fault is at a transient state and shall increase with time. Our models suggest that the current, Plio-Quaternary phase, requires moderate to null opening of the window. The northern toroidal cell gradually built up while the mantle flowed from the front of the continental unit towards the oceanic unit. The slab window will be an additional outlet for mantle flow in the north, and mantle is expected to flow through the window, reshaping the toroidal cell and promoting an increasingly faster rollback of the southern unit. Trenchward sublithospheric mantle drag will grow stronger through time in the south than in the north, that integrates into a net shear force that excites dextral shear in the NAT, CHSZ and Kefalonia. Because it controls upper plate tectonics, we thus anticipate that the further modification of mantle flow, in particular its diversion through the Kefalonia Fault, will foster even more dextral shear in the CHSZ and could participate to the connection of the NAF to the Kefalonia Fault through a discrete, curvilinear strike-slip fault (Fig. 12d).

Acknowledgements. This research was supported by the French ANR GiSeLE project and the European TOPO-Europe project. Models have been performed at the Laboratory of Experimental Tectonics of the University Roma Tre. We thank Thibault Duretz and an anonymous referee for their helpful and constructive reviews. We also thank F. Corbi for helping us during laboratory work, and L. Jolivet for sharing his maps. Thanks to Wiki Royden and the MEDUSA project for stimulating this work.

Edited by: T. Gerya

\section{References}

Adrian, R. J.: Particle imaging techniques for experimental fluid mechanics, Ann. Rev. Fluid Mech., 23, 261-304, 1991.

Amante, C. and Eakins, B. W.: ETOPO1 1 Arc-Minute Global Relief Model: Procedures, Data Sources and Analysis, NOAA Technical Memorandum NESDIS NGDC-24, 19, 2009.

Armijo, R., Meyer, B., Hubert, A., and Barka, A.: Westward propagation of the North Anatolian fault into the northern Aegean: timing and kinematics, Geology, 27, 267, 1999.

Baes, M., Govers, R., and Wortel, R.: Subduction initiation along the inherited weakness zone at the edge of a slab: Insights from numerical models, Geophys. J. Int., 184, 991-1008, 2011.

Bellahsen, N., Faccenna, C., and Funiciello, F.: Dynamics of subduction and plate motion in laboratory experiments: insights into the "plate tectonics" behavior of the Earth, J. Geophys. Res.-Sol. Ea., 110, B01401, doi:10.1029/2004JB002999, 2005.

Billen, M. I., Gurnis, M., and Simons, M.: Multiscale dynamics of the Tonga-Kermadec subduction zone, Geophys. J. Int., 153, 359-388, 2003.

Boschi, L., Faccenna, C., and Becker, T. W.: Mantle structure and dynamic topography in the Mediterranean Basin, Geophys. Res. Lett., 37, L20303, 2010.

Bowin, C., Purdy, G. M., Johnston, C., Shor, G., Lawver, L., Hartono, H. M. S., and Jezek, P.: Arc-continent collision in Banda Sea region, AAPG Bulletin, 64, 868-915, 1980.

Bradley, K. E., Vassilakis, E., Hosa, A., and Weiss, B. P.: Segmentation of the Hellenides recorded by Pliocene initiation of clockwise block rotation in Central Greece, Earth Planet. Sci. Lett., 362, 6-19, 2013.

Brun, J.-P. and Sokoutis, D.: 45 m.y. of Aegean crust and mantle flow driven by trench retreat, Geology, 38, 815-818, 2010.

Carter, D. J., Audley-Charles, M. G., and Barber, A. J.: Stratigraphical analysis of island arc-continental margin collision in eastern Indonesia, J. Geol. Soc. Lond., 132, 179-198, 1976.

Cazenave, A., Souriau, A., and Dominh, K.: Global coupling of Earth surface topography with hotspots, geoid and mantle heterogeneities, Nature, 340, 54-57, 1989.

Chapple, W. M. and Tullis, T. E.: Evaluation of the forces that drive the plates, J. Geophys. Res., 82, 1967-1984, 1977.

Cloos, M.: Lithospheric buoyancy and collisional orogenesis: subduction of oceanic plateaus, continental margins, island arcs, spreading ridges, and seamounts, Geol. Soc. Am. Bull., 105, 715-737, 1993.

CMT: Global Centroid-Moment-Tensor Project, available at: http: //www.globalcmt.org, 2011.

Davy, P. and Cobbold, P. R.: Experiments of a 4-layered continental lithosphere, Tectonophysics, 188, 1-25, 1991.

De Franco, R., Govers, R., and Wortel, R.: Dynamics of continental collision: influence of the plate contact, Geophys. J. Int., 174, 1101-1120, 2008.

Dermitzakis, M. and Papanikolaou, D.: Paleogeography and geodynamics of the Aegean region during the Neogene, in: Annales Géologiques des Pays Helléniques, VIIth Int. Congress on Mediterranean Neogene, 245-289, 1981.

Doutsos, T.: Stress and deformation patterns in the Aegean region, J. Struct. Geol., 23, 455-472, 2001.

Duretz, T. and Gerya, T.V.: Slab detachment during continental collision: Influence of crustal rheology and interaction with lithospheric delamination, Tectonophysics, in press, 
doi:10.1016/j.tecto.2012.12.024, 2013.

Dvorkin, J.: Narrow subducting slabs and the origin of backarc basins, Tectonophysics, 227, 63-79, 1993.

Espurt, N., Funiciello, F., Martinod, J., Guillaume, B., Regard, V., Faccenna, C. and Brusset, S.: Flat subduction dynamics and deformation of the South American plate: insights from analog modeling, Tectonics, 27, TC3011, 2008.

Evangelidis, C. P., Liang, W.-T., Melis, N. S., and Konstantinou, K. I.: Shear wave anisotropy beneath the Aegean inferred from SKS splitting observations, J. Geophys. Res., 116, B04314, doi:10.1029/2010JB007884, 2011.

Faccenda, M. and Capitanio, F. A.: Seismic anisotropy around subduction zones: Insights from three-dimensional modeling of upper mantle deformation and SKS splitting calculations, Geochem. Geophy. Geosy., 14, 243-262, 2013.

Faccenna, C. and Becker, T. W.: Shaping mobile belts by smallscale convection, Nature, 465, 602-605, 2010.

Faccenna, C., Heuret, A., Funiciello, F., Lallemand, S., and Becker, T. W.: Predicting trench and plate motion from the dynamics of a strong slab, Earth Planet. Sci. Lett., 257, 29-36, 2007.

Faccenna, C., Molin, P., Orecchio, B., Olivetti, V., Bellier, O., Funiciello, F., Minelli, L., Piromallo, C., and Billi, A.: Topography of the Calabria subduction zone (southern Italy): clues for the origin of Mt. Etna, Tectonics, 30, TC1003, 2011.

Forsyth, D. and Uyeda, S.: On the relative importance of the driving forces of plate motion, Geophys. J. Roy. Astron. Soc., 43, 163200, 1975.

Funiciello, F., Faccenna, C., Giardini, D., and RegenauerLieb, K.: Dynamics of retreating slabs: 2. Insights from threedimensional laboratory experiments, J. Geophys. Res., 108, 2207, doi:10.1029/2001JB000896, 2003.

Funiciello, F., Faccenna, C., and Giardini, D: Role of lateral mantle flow in the evolution of subduction systems: insights from laboratory experiments, Geophys. J. Int., 157, 1393-1406, 2004.

Funiciello, F., Moroni, M., Piromallo, C., Faccenna, C., Cenedese, A., and Bui, H. A.: Mapping mantle flow during retreating subduction: laboratory models analyzed by feature tracking, J. Geophys. Res., 111, B03402, doi:10.1029/2005JB003792, 2006.

Funiciello, F., Faccenna, C., Heuret, A., Lallemand, S., di Giuseppe, E., and Becker, T. W.: Trench migration, net rotation and slab mantle coupling, Earth Planet. Sci. Lett., 271, 233-240, 2008.

Gautier, P., Brun, J.-P., Moriceau, R., Sokoutis, D., Martinod, J., and Jolivet, L.: Timing, kinematics and cause of Aegean extension: a scenario based on a comparison with simple analogue experiments, Tectonophysics, 315, 31-72, 1999.

Gérault, M., Becker, T. W., Kaus, B. J. P., Faccenna, C., Moresi, L., and Husson, L.: The role of slabs and oceanic plate geometry in the net rotation of the lithosphere, trench motions, and slab return flow, Geochem. Geophy. Geosy., 13, 4001, 2012.

Gesret, A., Laigle, M., Diaz, J., Sachpazi, M., Charalampakis, M., and Hirn, A.: Slab top dips resolved by teleseismic converted waves in the Hellenic subduction zone, Geophys. Res. Lett., 38, L20304, doi:10.1029/2011GL048996, 2011.

Govers, R. and Wortel, M. J. R.: Lithosphere tearing at STEP faults: response to edges of subduction zones, Earth Planet. Sci. Lett., 236, 505-523, 2005.
Guillaume, B., Martinod, J., and Espurt, N.: Variations of slab dip and overriding plate tectonics during subduction: insights from analogue modelling, Tectonophysics, 463, 167-174, 2009.

Guillaume, B., Funiciello, F., Faccenna, C., Martinod, J., and Olivetti, V.: Spreading pulses of the Tyrrhenian Sea during the narrowing of the Calabrian slab, Geology, 38, 819-822, 2010.

Gurnis, M.: Phanerozoic marine inundation of continents driven by dynamic topography above subducting slabs, Nature, 364, 589593, 1993.

Hager, B. H. and Clayton, R. W.: Constraints on the structure of mantle convection using seismic observations, flow models, and the geoid, in: Mantle Convection, edited by: Peltier, R. W., Gordon and Breach, New York, 657-763, 1989.

Hager, B. H., Clayton, R. W., RIchards, M. A., Comer, R. P., and Dziewonski, A. M.: Lower mantle heterogeneity, dynamic topography and the geoid, Nature, 313, 541-545, 1985.

Hamilton, W.: Tectonics of the Indonesian region, vol. 1078, US Geol. Surv. Prof. Pap., 1979.

Hatzfeld, D., Karagianni, A., Kassaras, I., Kiratzi, A., Louvari, E., Lyon-Caen, H., Makropoulos, K., Papadimitriou, P., Bock, G., and Prietsley, K.: Shear wave anisotropy in the upper mantle beneath the Aegean related to internal deformation, J. Geophys. Res., 106, 30737-30754, 2001.

Heuret, A., Funiciello, F., Faccenna, C., and Lallemand, S.: Plate kinematics, slab shape and back-arc stress: a comparison between laboratory models and current subduction zones, Earth Planet. Sci. Lett., 256, 473-483, 2007.

Husson, L.: Dynamic topography above retreating subduction zones, Geology, 34, 741-744, 2006.

Husson, L.: Trench migration and upper plate strain over a convecting mantle, Phys. Earth Planet. In., 212, 32-43, 2012.

Husson, L., Guillaume, B., Funiciello, F., Faccenna, C., and Royden, L. H.: Unraveling topography around subduction zones from laboratory models, Tectonophysics, 526, 5-15, 2012.

Jolivet, L., Faccenna, C., and Piromallo, C.: From mantle to crust: stretching the Mediterranean, Earth Planet. Sci. Lett., 285, 198209, 2009.

Jolivet, L., Faccenna, C., Huet, B., Labrousse, L., Le Pourhiet, L., Lacombe, O., Lecomte, E., Burov, E., Denèle, Y., Brun, J.-P., Philippon, M., Paul, A., Salaün, G., Karabulut, H., Piromallo, C., Monié, P., Gueydan, F., Okay, A. I., Oberhänsli, R., Pourteau, A., Augier, R., Gadenne, L., and Driussi, O.: Aegean tectonics: Strain localisation, slab tearing and trench retreat, Tectonophysics, 597-598, 1-33, 2013.

Kahle, H.-G., Muller, M. V., Mueller, S., and Veis, G.: The Kephalonia Transform Fault and the rotation of the Apulian Platform: evidence from satellite geodesy, Geophys. Res. Lett., 20, 651-654, 1993.

Kincaid, C. and Olson, P.: An experimental study of subduction and slab migration, J. Geophys. Res., 92, 13832-13840, 1987.

Kreemer, C. and Chamot-Rooke, N.: Contemporary kinematics of the southern Aegean and the Mediterranean Ridge, Geophys. J. Int., 157, 1377-1392, 2004.

Kreemer, C., Chamot-Rooke, N., and Le Pichon, X.: Constraints on the evolution and vertical coherency of deformation in the Northern Aegean from a comparison of geodetic, geologic and seismologic data, Earth Planet. Sci. Lett., 225, 329-346, 2004.

Le Stunff, Y. and Ricard, Y.: Topography and geoid due to mass anomalies, Geophys. J. Int., 122, 982-990, 1995. 
Loiselet, C., Husson, L., and Braun, J.: From longitudinal slab curvature to slab rheology, Geology, 37, 747-750, 2009.

Loiselet, C., Braun, J., Husson, L., Le Carlier de Veslud, C., Thieulot, C., Yamato, P., and Grujic, D.: Subducting slabs: Jellyfishes in the Earth's mantle, Geochem. Geophys. Geosyst., 11, Q08016, doi:10.1029/2010GC003172, 2010.

Long, M. D. and Silver, P. G.: Shear wave splitting and mantle anisotropy: measurements, interpretations, and new directions, Surv. Geophys., 30, 407-461, 2009.

Magni, V., van Hunen, J., Funiciello, F., and Faccenna, C.: Numerical models of slab migration in continental collision zones, Solid Earth, 3, 293-306, doi:10.5194/se-3-293-2012, 2012.

Malinverno, A. and Ryan, W. B. F.: Extension in the Tyrrhenian Sea and shortening in the Apennines as result of arc migration driven by sinking of the lithosphere, Tectonics, 5, 227-245, 1986.

Martinod, J., Funiciello, F., Faccenna, C., Labanieh, S., and Regard, V.: Dynamical effects of subducting ridges: insights from 3-D laboratory models, Geophys. J. Int., 163, 1137-1150, 2005.

Martinod, J., Guillaume, B., Espurt, N., Faccenna, C., Funiciello, F., and Regard, V.: Effect of ridge subduction on slab geometry and overriding plate deformation: insights from analogue modeling, Tectonophysics, 588, 39-55, 2013.

McClusky, S., Balassanian, S., Barka, A., Demir, C., Ergintav, S., Georgiev, I., Gurkan, O., Hamburger, M., Hurst, K., Kahle, H., Kastens, K., Kekelidze, G., King, R., Kotzev, V., Lenk, O., Mahmoud, S., Mishin, A., Nadariya, M., Ouzounis, A., Paradissis, D., Peter, Y., Prilepin, M., Reilinger, R., Sanli, I., Seeger, H., Tealeb, A., Toksöz, M. N., and Veis, G.: Global Positioning System constraints on plate kinematics and dynamics in the eastern Mediterranean and Caucasus, J. Geophys. Res., 105, 5695-5719, 2000.

Mitrovica, J. X., Beaumont, C., and Jarvis, G. T.: Tilting of continental interiors by the dynamical effects of subduction, Tectonics, 8, 1079-1094, 1989.

Morra, G., Regenauer-Lieb, K., and Giardini, D.: Curvature of oceanic arcs, Geology, 34, 877-880, 2006.

Nogueira, J., Lecuona, A., and Rodriguez, P. A.: Local field correction PIV, implemented by means of simple algorithms, and multigrid versions, Meas. Sci. Technol., 12, 1911-1921, 2001.

Papanikolaou, D. J. and Royden, L. H.: Disruption of the Hellenic arc: Late Miocene extensional detachment faults and steep Pliocene-Quaternary normal faults - or what happened at Corinth?, Tectonics, 26, TC5003, 2007.

Paul, A., Ben Mansour, W., Hatzfeld, D., Karabulut, H., Childs, D. M., Péquegnat, C., and Hatzidimitriou, P.: Mantle flow in the Aegea-Anatolia region imaged by SKS splitting measurements, in: EGU General Assembly Conference Abstracts, vol. 12 of EGU General Assembly Conference Abstracts, 8807 pp., 2010.

Pearce, F. D., Rondenay, S., Sachpazi, M., Charalampakis, M., and Royden, L. H.: Seismic investigation of the transition from continental to oceanic subduction along the western Hellenic Subduction Zone, J. Geophys. Res., 117, B07306, doi:10.1029/2011JB009023, 2012

Pérouse, E., Chamot-Rooke, N., Rabaute, A., Briole, P., Jouanne, F., Georgiev, I., and Dimitrov, D.: Bridging onshore and offshore present-day kinematics of central and eastern Mediterranean: Implications for crustal dynamics and mantle flow, Geochem. Geophys. Geosyst., 13, Q09013, doi:10.1029/2012GC004289, 2012.
Piromallo, C., Becker, T. W., Funiciello, F., and Faccenna, C.: Three-dimensional instantaneous mantle flow induced by subduction, Geophys. Res. Lett., 33, L08304, 2006.

Reilinger, R., McClusky, S., Paradissis, D., Ergintav, S., and Vernant, P.: Geodetic constraints on the tectonic evolution of the Aegean region and strain accumulation along the Hellenic subduction zone, Tectonophysics, 488, 22-30, 2010.

Ricard, Y., Fleitout, L., and Froidevaux, C.: Geoid heights and lithospheric stresses for a dynamic Earth, Ann. Geophys., 2, 267-286, 1984,

http://www.ann-geophys.net/2/267/1984/.

Rosenbaum, G., Gasparon, M., Lucente, F. P., Peccerillo, A., and Miller, M. S.: Kinematics of slab tear faults during subduction segmentation and implications for Italian magmatism, Tectonics, 27, TC2008, 2008.

Royden, L. H.: The tectonic expression slab pull at continental convergent boundaries, Tectonics, 12, 303-325, 1993.

Royden, L. H. and Husson, L.: Subduction with variations in slab buoyancy: models and application to the Banda and Apennine systems, in: Subduction Zone Geodynamics, edited by: Lallemand, S. and Funiciello, F., Springer-Verlag, Berlin, Heidelberg, 35-45, 2009.

Royden, L. H. and Papanikolaou, D. J.: Slab segmentation and late Cenozoic disruption of the Hellenic arc, Geochem. Geophy. Geosy., 12, Q03010, doi:10.1029/2010GC003280, 2011.

Russo, R. M. and Silver, P. G.: Trench-parallel flow beneath the Nazca plate from seismic anisotropy, Science, 263, 1105-1111, 1994.

Sachpazi, M.: Western Hellenic subduction and Cephalonia Transform: local earthquakes and plate transport and strain, Tectonophysics, 319, 301-319, 2000.

Salaün, G., Pedersen, H. A., Paul, A., Farra, V., Karabulut, H., Hatzfeld, D., Papazachos, C., Childs, D. M., and Pequegnat, C.: High-resolution surface wave tomography beneath the AegeanAnatolia region: constraints on upper-mantle structure, Geophys. J. Int., 190, 406-420, 2012.

Schellart, W. P.: Kinematics of subduction and subduction-induced flow in the upper mantle, J. Geophys. Res., 109, B07401, doi:10.1029/2004JB002970, 2004.

Spakman, W., Hall, R.: Surface deformation and slab-mantle interaction during Banda arc subduction rollback, Nature Geoscience, 3, 562-566, 2010.

Spakman, W., Wortel, M. J. R., and Vlaar, N. J.: The Hellenic subduction zone: a tomographic image and its geodynamic implications, Geophys. Res. Lett., 15, 60-63, 1988.

Speranza, F., Kissel, C., Islami, I., Hyseni, A., and Laj, C.: First paleomagnetic evidence for rotation of the Ionian Zone of Albania, Geophys. Res. Lett., 19, 697-700, 1992.

Speranza, F., Minelli, L., Pignatelli, A., and Chiappini, M.: The Ionian Sea: The oldest in situ ocean fragment of the world?, J. Geophys. Res., 117, B12101, doi:10.1029/2012JB009475, 2012.

Suckale, J., Rondenay, S., Sachpazi, M., Charalampakis, M., Hosa, A., and Royden, L. H.: High-resolution seismic imaging of the western Hellenic subduction zone using teleseismic scattered waves, Geophys. J. Int., 178, 775-791, 2009.

Sveen, J. K.: An introduction to MatPIV v.1.6.1, Eprint no. 2, Dept. of Mathematics, University of Oslo, available at: http://folk.uio. no/jks/matpiv/index2.html, 2004. 
Šengör, A. M. C., Tüysüz, O., Imren, C., Sakinç, M., Eyidoğan, H., Görür, N., Le Pichon, X., and Rangin, C.: The North Anatolian Fault: a new look, Annu. Rev. Earth Planet. Sci., 33, 37-112, 2005.

Tirel, C., Gueydan, F., Tiberi, C., and Brun, J.-P.: Aegean crustal thickness inferred from gravity inversion, geodynamical implications, Earth Planet. Sci. Lett., 228, 267-280, 2004.

van Hinsbergen, D., Snel, E., Garstman, S., Marunteanu, M., Langereis, C., Wortel, M., and Meulekamp, J.: Vertical motions in the Aegean volcanic arc: evidence for rapid subsidence preceding volcanic activity on Milos and Aegina, Mar. Geol., 209, 329345, 2004.

van Hinsbergen, D. J. J., Langereis, C. G., and Meulenkamp, J. E.: Revision of the timing, magnitude and distribution of Neogene rotations in the western Aegean region, Tectonophysics, 396, 134, 2005.

van Hunen, J., van den Berg, A. P., and Vlaar, N. J.: On the role of subducting oceanic plateaus in the development of shallow flat subduction, Tectonophysics, 352, 317-333, 2002.

Vassilakis, E., Royden, L., and Papanikolaou, D.: Kinematic links between subduction along the Hellenic trench and extension in the Gulf of Corinth, Greece: a multidisciplinary analysis, Earth Planet. Sci. Lett., 303, 108-120, 2011.
Weijermars, R. and Schmeling, H.: Scaling of Newtonian and non Newtonian fluid dynamics without inertia for quantitative modelling of rock flow due to gravity (including the concept of rheological similarity), Phys. Earth Planet. In., 43, 316-330, 1986.

Wessel, P. and Smith, W. H. F.: New, improved version of generic mapping tools released, EOS, T. Am. Geophys. U., 79, 579, 1998.

Wright, R.: Neogene paleobathymetry of the Mediterranean basen on benthic foraminifers from DSDP leg 42A, in: Initial Reports of the Deep Sea Drilling Project, edited by: Hsu, K., Montadert, L., and et al., Scripps. Inst. Oceanogr., 837-846, 1978.

Wu, B., Conrad, C. P., Heuret, A., Lithgow-Bertelloni, C., and Lallemand, S.: Reconciling strong slab pull and weak plate bending: the plate motion constraint on the strength of mantle slabs, Earth Planet. Sci. Lett., 272, 412-421, 2008.

Yáñez, G. and Cembrano, J.: Role of viscous plate coupling in the late Tertiary Andean tectonics, J. Geophys. Res., 109, B02407, doi:10.1029/2003JB002494, 2004.

Zhong, S. and Gurnis, M.: Controls on trench topography from dynamic models of subducted slabs, J. Geophys. Res., 99, 15683$15695,1994$. 